\title{
Squeezing the Peasants: Grain Extraction, Food Consumption and Rural Living Standards in Mao's China*
}

\author{
Robert Ash
}

\begin{abstract}
At the end of Mao's life farmers still accounted for some 80 per cent of China's population. Its declining share in GDP notwithstanding, agriculture continued to carry a heavy developmental burden throughout the Mao era. The production and distribution of grain - the wage good par excellence - held the key to fulfilling this role. But despite a pragmatic response to the exigencies of famine conditions in 1959-61, state investment priorities never adequately accommodated the economic, let alone the welfare needs of the farm sector. Thanks to the mechanism of grain re-sales to the countryside, the Chinese government's extractive policies were less brutal in their impact than those pursued by Stalin in the Soviet Union. Even so, a detailed national, regional and provincial analysis of grain output and procurement trends highlights the process of rural impoverishment which characterized China's social and economic development under Maoist planning.
\end{abstract}

The role of institutional change in agriculture - in particular, its ability to promote rapid and sustained farm development - has long been debated. The experience of China under the leadership of the Chinese Communist Party (CCP) is something of a cause célèbre in this respect. In less than three decades, the Chinese countryside underwent two institutional upheavals - collectivization in the 1950s, decollectivization in the 1980s - whose policy thrusts ran in exactly opposite directions.

Economists have long recognized the importance, even necessity, of institutional change as a source of farm output and productivity growth. But the conventional wisdom, strongly supported by empirical evidence, is that institutional change is only one of several elements that must be mobilized in support of such growth. In particular, economic measures and technical initiatives are thought to be at least as important as "getting institutions right." Changing the organizational framework of agriculture may have a positive impact on efficiency and growth. But the effect is likely to be one-off and short-term, and the effect of subsequent institutional adjustments may be merely incremental. By contrast, the potential benefits of economic

* I am grateful to the participants of the China Quarterly Conference (October 2005), at which a very different version of this article was initially presented, for comments and advice on how I might go about making a very diffuse paper more focused. I also take special pleasure in thanking Professor Colin White (La Trobe University, Melbourne, Australia) - a dear friend of almost half a century - for his insightful and encouraging comments from afar on an interim version of this article.

(c) The China Quarterly, 2006 doi: 10.1017/S0305741006000518 
policy initiatives and technical progress are less constrained, and offer a basis on which to make continuous improvements.

Insufficient recognition of the beneficial, mutually-reinforcing complementarity between institutional, economic and technological measures characterized Chinese government thinking on farm policy between the 1950s and 1970s. For a time, collectivization was thought to be impossible until China's agriculture had been mechanized. By the time Mao made his speech that launched the first "high tide of cooperativization,"1 the relationship between the two had been reversed, with collectivization now a prior condition of farm mechanization. Implicit in the new emphasis was the belief that technical progress in agriculture should not be solely identified with the use of modern capital-intensive technology. Labour-intensive improvements - close planting, more multiple cropping, better use of organic fertilizers were also important. So was the Nurksean prescription of rural capital formation based on mass labour mobilization. Such measures were most effectively pursued in an institutional framework which afforded tight control over the farm workforce. In China the outcome of this one-sided emphasis on institutions was a legacy of technological backwardness in agriculture. The economic implications of this for a sector which in the 1970s still accounted for well over three-quarters of total employment, and which provided 70 per cent of light industry's material inputs and about half of the state's budgetary revenue, were serious.

In 1949 its ideological and historical roots committed the CCP to a strategy of institutional change as the main engine of growth in the rural sector. The first major post-1949 campaign was an increasingly radicalized land reform, which destroyed the political and economic power base of the landlord-gentry class. Through the distribution of land and other assets to poor and landless peasants, it also consolidated mass support for the Party in the countryside. Land reform was, however, a temporizing measure: the first step of a series of agrarian changes that would lead to full collectivization. As the experience of the Soviet Union had already demonstrated, implementing collectivization in a framework of dirigiste, central planning without simultaneously damaging farm incentives and undermining efficiency posed a formidable challenge. But for the Chinese government, such considerations were less important than the promise of unprecedented control over the labour force and agricultural output, offered by further expropriation, socialization and the creation of new and larger organizational forms. By such means, the government's all-important extractive role vis-à-vis the peasants would be fulfilled. Thereby too, the priority goal of rapid industrialization - which depended on securing from farmers a real

1. Mao Zedong, "Guanyu nongye hezuohua wenti" ("On the question of agricultural co-operativization"), 31 July 1955 (printed in Xinhua yuebao (New China Monthly), Vol. 73, No. 11 (1955), pp. 1-8). 
surplus (food, raw materials and exportable goods) and a financial surplus - would also be achieved. Except when, in the early 1960s, famine forced a temporary adjustment of investment priorities, the imperative of heavy industrialization was the ultimate determinant of farm policy throughout the Mao period.

The main concern of this article is with the impact of the government's extractive policies on Chinese peasants, with some consideration also given to the nature and rationale of agricultural policy. I offer a brief review of farm production, but it is with peasants as consumers that I am more concerned in an attempt to assess changes in their living standards during the Mao era. Given the pervasive nature of rural poverty that was part of the legacy of this period, much of my analysis necessarily focuses on grain.

Other authors have of course investigated these issues. Perhaps the most notable contributions are those of Nicholas Lardy and Kenneth Walker, ${ }^{2}$ which remain hugely insightful more than 20 years after their publication, offering valuable comment on the impact of Maoist farm policies on rural consumption and living standards. Neither writer had access, however, to consistent time-series estimates of grain output, procurement and urban and rural-resales for the entire Mao era, which became available only after the publication of their books. ${ }^{3}$ As far as I am aware, this is the first article to make use of these data to investigate the rural implications of grain extraction throughout the planning period up to Mao's death.

\section{Agricultural Development in the Mao Period}

Tables 1 and 2 seek to capture critical dimensions of the physical profile, resource endowment and performance of China's agriculture between 1952 (the eve of the First Five-Year Plan [FFYP]) and 1976. The two tables are highly revealing. Concealed in them is the essence of the labour mobilization approach, without which - given the disproportionate allocation of government budgetary spending ${ }^{4}$ and investment to sectors other than agriculture - the impressive

2. E.g., Nicholas R. Lardy, Agriculture in China's Modern Economic Development (Cambridge: Cambridge University Press, 1983), esp. ch. 4. Kenneth R. Walker, Food Grain Procurement and Consumption in China (Cambridge: Cambridge University Press, 1984). Also useful is Thomas Lyons, Economic Integration and Planning in Maoist China (New York: Columbia University Press, 1987).

3. Walker did subsequently gain access to these materials, of which he made extensive use in a study, published posthumously, of the Great Leap Forward ("Food and mortality in China during the Great Leap Forward," in Robert F. Ash (ed.), Agricultural Development in China, 1949-1989: The Collected Papers of Kenneth R. Walker (Oxford: Oxford University Press, 1998), pp. 106-147).

4. Table 1 shows that throughout the period of the FFYP tax revenue from agriculture exceeded government budgetary spending in support of farming. Not that the proceeds of agricultural taxes shown in the table capture the full extent of agriculture's fiscal burden: from 1953 onwards, the compulsory sale to the state of farm produce (above all, grain - par excellence, the wage good) at prices fixed by the state below the market level was a much more important source of development support. 
Table 1: China's Agriculture - Supply of Land, Labour and Capital, 1952-76

\begin{tabular}{|c|c|c|c|c|}
\hline & 1952 & 1957 & 1965 & 1976 \\
\hline \multicolumn{5}{|l|}{ Population (m) } \\
\hline Total population (TP) & 574.8 & 646.5 & 725.4 & 937.2 \\
\hline Rural population (RP) & 503.2 & 547.0 & 594.9 & 773.8 \\
\hline $\mathrm{RP}$ as $\% \mathrm{TP}$ & 87.5 & 84.6 & 82.0 & 82.6 \\
\hline \multicolumn{5}{|l|}{ Employment (m) } \\
\hline Total employment & 207.3 & 237.7 & 286.7 & 388.3 \\
\hline Rural employment & 182.4 & 205.7 & 235.3 & 301.4 \\
\hline Agricultural employment & - & 192.0 & 225.0 & 286.5 \\
\hline Agric. share of total employment (\%) & - & 80.8 & 78.5 & 73.8 \\
\hline Agric. share of rural employment (\%) & - & 93.3 & 95.6 & 95.1 \\
\hline \multicolumn{5}{|l|}{ Area (m ha) } \\
\hline Arable area & 107.9 & 111.8 & 103.6 & 99.4 \\
\hline Irrigated area & 20.0 & 27.3 & 33.1 & 45.0 \\
\hline Irrigated area as $\%$ arable area & 18.5 & 24.4 & 31.9 & 45.3 \\
\hline Total sown area & 141.3 & 157.2 & 143.3 & 149.7 \\
\hline Multiple cropping index (\%) & 131.0 & 140.6 & 138.3 & 150.6 \\
\hline \multicolumn{5}{|l|}{ Farm mechanization } \\
\hline Agricultural machine power (m kw) & - & 1.2 & 10.9 & 117.5 \\
\hline $\begin{array}{l}\text { Number of large and medium } \\
\text { tractors (units) }\end{array}$ & 1,307 & 14,674 & 72,599 & 397,000 \\
\hline $\begin{array}{l}\text { Number of small (incl. hand) tractors } \\
\text { (units) }\end{array}$ & - & - & 3,956 & 825,000 \\
\hline \multicolumn{5}{|l|}{ Chemical fertilizers } \\
\hline Total application (m tons, nutrient) & 0.04 & 0.15 & 1.73 & 5.24 \\
\hline Av. application per sown ha $(\mathrm{kg})$ & 0.28 & 0.95 & 12.07 & 35.00 \\
\hline \multicolumn{5}{|l|}{$\begin{array}{l}\text { Fiscal resource flows to and from } \\
\text { agriculture (m yuan) }\end{array}$} \\
\hline $\begin{array}{l}\text { Government expenditure on } \\
\text { agriculture }\end{array}$ & 904.0 & $2,350.0$ & $5,498.0$ & $11,049.0$ \\
\hline $\begin{array}{l}\text { As } \% \text { of total government } \\
\text { expenditure }\end{array}$ & 4.03 & 7.94 & 11.95 & 13.71 \\
\hline Tax revenue from agriculture & $2,751.0$ & $2,967.0$ & $2,578.0$ & $2,914.0$ \\
\hline As $\%$ of total tax revenue & 22.99 & 19.16 & 12.62 & 7.14 \\
\hline \multicolumn{5}{|l|}{ Investment in agriculture (m yuan) } \\
\hline $\begin{array}{l}\text { Agricultural capital construction } \\
\text { investment }\end{array}$ & 774.0 & $1,187.0$ & $2,497.0$ & $4,104.0$ \\
\hline $\begin{array}{l}\text { As } \% \text { total capital construction } \\
\text { investment }\end{array}$ & 8.6 & 8.3 & 13.9 & 10.9 \\
\hline
\end{tabular}

\section{Sources:}

Ministry of Agriculture, Zhongguo nongcun jingji tongji dachuan, 1949-86 (Compendium of Rural Economic Statistics for China, 1949-86), hereafter Dachuan, (Beijing: Nongye chubanshe, 1989); National Bureau of Statistics (NBS), Xin Zhongguo wushi nian nongye tongji ziliao (New China - 50 Years of Agricultural Statistical Materials), hereafter 50NNYZL (Beijing: Tongji chubanshe, 2000); NBS, Xin Zhongguo wushi nian tongji ziliao huibian (Comprehensive Collection of Statistical Materials for 50 Years of New China), hereafter 50NTJZL (Beijing: Tongji chubanshe, 1999); NBS, Zhongguo nongcun tongji nianjian (China Rural Statistical Yearbook) (Beijing: Tongji chubanshe, various issues); NBS and Ministry of Labour and Social Security, Zhongguo laodong tongji nianjian, 2004 (China Labour Statistical Yearbook, 2004) (Beijing: Tongji chubanshe, 2004); NBS, Zhongguo guding zichan touzi tongji ziliao, 1950-1985 (Statistical Materials on Fixed Capital Investment in China, 1950-85), hereafter ZGGD (Beijing: Tongji chubanshe, 1987). 
Table 2: China's Agricultural Performance, 1952-76

\begin{tabular}{|c|c|c|c|c|}
\hline & 1952 & 1957 & 1965 & 1976 \\
\hline \multicolumn{5}{|c|}{$\begin{array}{l}\text { Gross value output (GVAO) (m } \\
\text { yuan)* }\end{array}$} \\
\hline All agriculture & 41,700 & 53,670 & 58,960 & 79,930 \\
\hline Crop cultivation & 36,490 & 45,550 & 48,480 & 64,140 \\
\hline Forestry & 290 & 930 & 1,200 & 1,510 \\
\hline Animal husbandry & 4,790 & 6,900 & 8,270 & 11,370 \\
\hline Fisheries & 130 & 290 & 1,010 & 1,510 \\
\hline \multicolumn{5}{|c|}{ With all agriculture as 100.0} \\
\hline Crop cultivation & 87.5 & 84.9 & 82.2 & 80.2 \\
\hline Forestry & 0.7 & 1.7 & 2.0 & 1.9 \\
\hline Animal husbandry & 11.5 & 12.9 & 14.0 & 14.2 \\
\hline Fisheries & 0.3 & 0.5 & 1.7 & 1.9 \\
\hline \multicolumn{5}{|c|}{$\begin{array}{l}\text { Average GVAO per head of } \\
\text { agricultural employed labour } \\
\text { (yuan) }\end{array}$} \\
\hline All agriculture & $240.7 \dagger$ & 279.5 & 262.0 & 279.0 \\
\hline Crop cultivation & $221.7 \$$ & $249.7 \ddagger$ & $226.8 \ddagger$ & $235.7 \ddagger$ \\
\hline \multicolumn{5}{|l|}{ Total output (m tons) } \\
\hline All food grains & 163.9 & 195.1 & 194.5 & 286.3 \\
\hline Oilseeds & 4.2 & 4.2 & 3.6 & 4.0 \\
\hline Cotton & 2.3 & 2.6 & 1.9 & 2.1 \\
\hline Meat (incl. poultry) & 3.4 & 4.0 & 5.5 & 7.8 \\
\hline Aquatic products & 1.7 & 3.1 & 3.0 & 4.5 \\
\hline Sugar & 7.6 & 11.9 & 15.4 & 19.6 \\
\hline \multicolumn{5}{|l|}{ Average yield (kg/ha) } \\
\hline All food grains & 1,322 & 1,460 & 1,626 & 2,371 \\
\hline Oilseeds & 734 & 605 & 702 & 693 \\
\hline Cotton & 234 & 284 & 419 & 417 \\
\hline Sugar & 34,839 & 27,918 & 29,454 & 21,785 \\
\hline \multicolumn{5}{|c|}{$\begin{array}{l}\text { Average output per head of total } \\
\text { population }(\mathrm{kg})\end{array}$} \\
\hline All food grains & 285.1 & 301.8 & 268.1 & 305.5 \\
\hline Oilseeds & 7.3 & 6.5 & 5.0 & 4.3 \\
\hline Meat (incl. poultry) & 5.9 & 6.2 & 7.6 & 8.3 \\
\hline Aquatic products & 3.0 & 4.8 & 4.1 & 4.8 \\
\hline Sugar & 13.2 & 18.4 & 21.2 & 20.9 \\
\hline
\end{tabular}

Notes:

* These figures are based on constant 1957 prices.

$\dagger$ Assuming that agricultural employment was $95 \%$ of rural employment.

+ Assuming that crop cultivation absorbed $95 \%$ of all agricultural employed. Sources:

Table 1; Ministry of Agriculture, Compendium of Rural Economic Statistics, 194986; New China - 50 Years of Agricultural Statistical Materials 
expansion in irrigated area and multiple cropping shown in Table 1 could not have taken place. The institutional bias of farm policy in the 1950s is highlighted in the relative neglect of the use of modern farm inputs. This applied to both working capital, represented by chemical fertilizers, ${ }^{5}$ and fixed capital (such as tractors) in promoting agricultural growth. Given existing resource constraints, this entailed a significant cost. For example, despite their mobilizational capacities, the collectives failed to generate sufficient labour and draught animals to meet the demands for increased output placed upon them. ${ }^{6}$ The fact that there were on average fewer than two tractors per hundred collectives merely highlights the potential impact of delayed farm mechanization.

The fiscal burden carried by the farm sector during the 1950s is captured in the finding that state spending on agriculture was less than tax revenue from this source (from the mid-1960s this was reversed). The farm sector's low investment share was disproportionate to the developmental burden it carried, especially since the meagre resources it received for capital construction under the FFYP were mainly directed to water control construction on the Yellow River, the gains from which were questionable. ${ }^{7}$ However, there are two qualifications to this gloomy picture. First, it takes no account of the farm sector's own potential for investment, which the central government believed was considerable (during the FFYP period farm households were reported to have undertaken net capital investment of more than 10 billion yuan, almost half the value of basic capital construction investment in agriculture in the same period). ${ }^{8}$ Secondly,

5. In 1965, China's average consumption of chemical fertilizer per hectare of arable area was about two-thirds of the world average and at about the same level as in the USSR. At the time of collectivization, the gap between China and many parts of the world, though not India, was even greater.

6. K.R. Walker, "Organization of agricultural production," in A. Eckstein, W. Galenson and Ta-ching Liu (eds.), Economic Trends in Communist China (Chicago: Aldine Publishing Co., 1968), pp. 397-358. The shortage of labour and draught animals was exacerbated by the negative impact of collectives on labour incentives, and by the slaughter and ill-care of large numbers of oxen and water buffaloes.

7. E.g. see Judith Shapiro, Mao's War Against Nature: Politics and the Environment in Revolutionary China (Cambridge: Cambridge University Press, 2001), pp. 49-51. A revealing comment on irrigation problems during the FFYP is available in Jihua jingji (Planned Economy), No. 10 (1957), pp. 15-17. See also Choh-Ming Li's comment, "22 large irrigation projects have been initiated during the 5 years (195357), each requiring 2 to 4 years for completion; by the end of 1957 only a few had been completed - with poor results," Economic Development of Modern China: An Appraisal of the First Five Years of Industrialization (Berkeley \& Los Angeles: University of California Press, 1959), p. 67. After 45 years, Li's analysis still repays careful reading and offers valuable insights into the rationale and impact of the FFYP.

8. The estimate of farm household investment is from Jihua jingji, No. 10 (1957), pp. 1-2. This figure is, however, likely to refer to fixed investment, since another Chinese source indicates that "farmers' self-investment, incl. additions to working capital, totalled 17 b. yuan" during 1953-57 (Nicholas R. Lardy, Agriculture in Modern China's Development (Cambridge: Cambridge University Press, 1983), p. 138). Annual estimates of capital construction investment in agriculture are given in National Bureau of Statistics (NBS), Zhongguo guding zichan touzi tongji ziliao, 195085 (Statistical Materials on Fixed Capital Investment in China, 1950-85), hereafter ZGGD (Beijing: Tongji chubanshe, 1987), p. 97. 
the central budget was not the only source of budgetary support for farming. Official NBS estimates show, for example, that during 195357, 735 million yuan were invested in the chemical fertilizer and farm machinery industries. ${ }^{9}$

A striking feature of Table 1 is the interruption of progress that occurred between 1957 and 1965. This was of course a reflection of the Great Leap Forward, the social and economic impact of which prompted a marked change in the thrust of China's farm policy through the reversal of sectoral investment priorities. This has sometimes been interpreted as a shift towards an "agriculture first" strategy. But if the new approach showed the CCP's concern with "the welfare of the masses,"10 the underlying motivation was less one of altruism than of realpolitik. The fundamental imperative that the Party sought to fulfil was that of maintaining its authority in the wake of the great famine of 1959-61. What is undeniable is that from the early 1960s, not only was there a significant rise in agricultural investment itself, ${ }^{11}$ but the allocation of industrial investment also favoured the farm sector by prioritizing agricultural machinery and chemical fertilizer production. Significant too was the launch of smallscale rural industrialization, which gave farmers access to low-grade, but cheap and serviceable additions to fixed and working capital.

These were important departures from previous farm policies, and although they were prompted by the exigencies of the time, it would be wrong to regard them as mere tactical expedients. As Table 1 suggests, increased availability of mechanized power, greater use of chemical fertilizers and irrigated area expansion all continued through and beyond the 1960s. However, the increased supply of fixed and working farm capital is not necessarily an accurate guide to their economic impact. Introduction of farm machinery favoured a small number of regions to the near exclusion of many others. ${ }^{12}$ Nor was

9. I.e. $465 \mathrm{~m}$ yuan in chemical fertilizers, $270 \mathrm{~m}$ yuan in production and repair facilities for farm machinery (ibid. p. 103).

10. Robert F. Dernberger, "Agriculture in communist development strategy," in Randolph Barker and Radha Sinha (eds.) with Beth Rose, The Chinese Agricultural Economy (Boulder, CO: Westview Press, 1982), p. 74.

11. In contrast to the FFYP years, when agriculture received a mere $7.1 \%$ of aggregate capital construction investment, in 1958-62 the corresponding figure was $11.3 \%$, and for the recovery years (1963-65) $17.6 \%$. For the rest of the Mao period, it averaged between $10 \%$ and $11 \%$.

12. E.g. in 1978 Hebei, Henan, Shandong and Jiangsu accounted for $34 \%$ of total agriculture machine power (NBS, Xin Zhongguo wushi nian tongji ziliao huibian (Comprehensive Collection of Statistical Materials for 50 Years of New China), hereafter 50NTJZL (Beijing: Tongji chubanshe, 1999), p. 120), while over 37\% of all large and medium-sized tractors were in Hebei, Shandong, Heilongjiang and Liaoning (NBS, Xin Zhongguo wushi nian nongye tongji ziliao (New China - 50 Years of Agricultural Statistical Materials), hereafter 50NNYZL (Beijing: Tongji chubanshe, 2000), p. 120). Average grain yields in 1978 in these 6 provinces ranged from $22 \%, 20 \%$ and $18 \%$ below the corresponding national figure in Heilongjiang, Hebei and Henan, to $1 \%, 14 \%$ and $44 \%$ above it (Shandong, Liaoning and Jiangsu) (50NNYZL, p. 242). These ratios hardly point to farm mechanization's uniformly positive impact on land productivity, although estimating the relationship between farm mechanization and 
farm machinery always used for agricultural production: tractors were often valued more as a means of transport than for cultivation purposes. ${ }^{13}$ That chemical fertilizers had a significant positive impact on yields in the 1960s and 1970s is not in doubt. But at first fairly crude nitrogenous fertilizers produced in local, small-scale factories were often used as a means of securing rapid rises in yields. By contrast, insufficient attention was given to crucial long-term considerations of soil types, nutrient requirements and application techniques, and the demands of complementarity between seed varieties, water availability and agricultural chemicals. In the 1970s, the situation changed, as policy makers began to address such deficiencies, and at the end of the decade much of the sown areas of maize, wheat and - especially - rice was planted under high-yielding fertilizer-responsive seed varieties. ${ }^{14}$ Most impressive of all and central to the gains from agricultural technical progress was the impressive expansion in irrigated area. During 1965-76, the "effectively-irrigated area" rose from 33.1 million to 45 million hectares. ${ }^{15}$ From a longerterm perspective, this was probably the most important infrastructural legacy of developments that took place during the Mao period. ${ }^{16}$

It would be misleading to describe these developments as merely cosmetic. Whether they signified the implementation of a lasting "agriculture first" strategy depends on how one interprets the available evidence. From a sectoral perspective, state investment continued to be directed overwhelmingly to industry, not agriculture.

footnote continued

productivity is enormously complicated. On Kit Tam's study (China's Agricultural Modernization: The Socialist Mechanization Scheme (London: Croom Helm, 1985)) remains an essential source for anyone wishing to explore the rationale and impact of farm mechanization - especially tractorization - in China.

13. This applied even to the small "walking tractors," produced in large numbers in order to accommodate the smallness of scale of Chinese farming. The use of tractors for purposes other than ploughing may have reflected the more critical transportation bottleneck: "moving bulky manures, seeds, seedlings, harvested crops, etc. consumes more labour power than ploughing," Thomas Wiens, "Technological change," in Barker and Sinha, The Chinese Agricultural Economy, p. 112.

14. Over $80 \%$ of rice was sown under such varieties in 1978. Bruce Stone, "Basic agricultural technology under reform," in Y.Y. Kueh and R.F. Ash (eds.), Economic Trends in Chinese Agriculture: The Impact of Post-Mao Reforms (Oxford: Clarendon Press, 1993), p. 335.

15. Ministry of Agriculture, Zhongguo nongcun jingji tongji dachuan, 1949-86 (Compendium of Rural Economic Statistics for China, 1949-86), hereafter Dachuan (Beijing: Nongye chubanshe, 1989), p. 318. In 1952 the corresponding figure was $20 \mathrm{~m}$ ha. "Effectively-irrigated" (youxiao guangai) means "level land which has water sources and complete sets of irrigation facilities to lift and move adequate water for irrigation purposes under normal conditions" (Stone, "Basic agricultural technology under reform," p. 312, Table 9.1). Reference to "normal" conditions is significant, since floods and drought frequently precipitated abnormal conditions. E.g. in ten out of the 15 years for which data are available between 1960 and 1976 , over $30 \mathrm{~m}$ ha were affected by natural disasters (and 20-30 $\mathrm{m}$ ha in three more) (50NNYZL, p. 29).

16. The case is argued vigorously by Chris Bramall in his Sources of Chinese Economic Growth, 1978-1996 (Oxford: Oxford University Press, 2000), esp. pp. 132-147. 
At the same time, although the farm sector's share of such investment fell off from the level of 1958-65, and especially the record high in the immediate aftermath of the Leap (1962-65), between the mid-1960s and the end of the 1970s, it remained significantly higher than during the FFYP (1953-57). ${ }^{17}$ In addition, the share of heavy industrial development in agriculture-support industries, such as chemical fertilizers and farm machinery, ran at record levels between 1965 and the end of the Mao period. ${ }^{18}$

The view that institutional constraints - inefficiencies associated with the persistence of the three-tier system of commune, production brigade and production team - were more serious than irrational sectoral allocations of state investment in undermining accelerated farm output growth is one which I share. A return to price planning, the re-opening of rural markets and, most radically, the sanctioning of contracts between individual farm households and production teams ${ }^{19}$ were central to the rural sector's recovery, in the early 1960s, from previous famine conditions. But the retreat from core Maoist and socialist values was only temporary, and in the second half of the 1960s there was a return to the collectivist ethos and to production planning which lasted until Mao's death. That this should have occurred just as the Cultural Revolution was unfolding is not coincidental. $^{20}$ Nor is the emergence of a renewed emphasis on local and regional rural self-sufficiency, in terms of both consumption and investment, encapsulated in the Cultural Revolution's "dazhai model", of agricultural development.

The data in Table 2 highlight some of the strengths and weaknesses of agricultural policies during the Mao era. At the most aggregative level, they show that there was a distinct slowing in the rate of agricultural growth after 1957 that was not only the product of the disastrous Great Leap Forward - recovery had, after all, taken place by 1965 - but that continued throughout the Cultural Revolution decade (1966-76). ${ }^{21}$ Bearing in mind that population growth continued after $1965,{ }^{22}$ the adverse implications of this are clear. Given the steady contraction in

17. Relevant data can be found in Ash, "The peasant and the state," The China Quarterly, No. 127 (1991), esp. pp. 496-502.

18. Ibid.

19. For evidence of these precursors of the responsibility systems of the early 1980s, see C.S. Chen and C.P. Ridley, Rural People's Communes in Lien-Chiang: Documents Concerning Communes in Lien-chiang County, Fukien Province, 1962-63, esp. Documents V and VI; also K.R. Walker, "Chinese agriculture during the period of readjustment, 1978-83," The China Quarterly, No. 100 (1984), p. 786.

20. Cf. Nicholas R. Lardy: "increased direct planning ... coincided with a sharp political shift to the left that drastically reduced rural periodic markets in most of China," Agriculture in China's Modern Economic Development (Cambridge: Cambridge University Press, 1983), p. 46.

21. The estimates in Table 2 indicate an average rate of GVAO increase of 5.2\% p.a. (1952-57), and 2.1\% p.a. (1957-76). The corresponding figure for $1965-76$ is $2.8 \%$ p.a.

22. The average rate of natural increase of total population was $2.4 \%$ p.a. during $1965-76$ 
arable area that took place after $1957,,^{23}$ a comparison of the output growth of individual products points to a mixed assessment of China's agricultural performance. On the one hand, increases in grain production were sustained by quite impressive improvements in yields, especially after 1965. On the other hand, the yield performance of cotton and oilseeds was much more disappointing; and increased output of sugar was only made possible by a major expansion in its sown area.

Another striking finding is the absence of any significant degree of economic diversification in the farm sector. In the early 1950s agriculture was dominated by grain; at the end of the 1970s, although the extent of such dominance had declined, conditions remained basically unchanged. The contrast here with post-1978 rural economic diversification is very noticeable. It reflects the role of grain as the basic wage good - a role that was underlined in the Cultural Revolution by the imperative, on geo-strategic security grounds, of local as well as national grain self-sufficiency.

But in the end, the clearest evidence of Chinese agriculture's inability to fulfil all its developmental demands is captured in trends in per capita grain production. Having peaked at 307 kilograms in 1956, average per capita grain output did not re-attain this level until 1975. Between the last three years of the FFYP (1955-57) and the last three years of Mao's life (1974-76), it increased from 302.6 to $305.5 \mathrm{~kg}$, a cumulative increase of less than one percentage point. Given the heavy burden of extraction on the agricultural sector - and bearing in mind that rural food self-sufficiency in China required $275-300 \mathrm{~kg}$ of raw grain to be made available per head ${ }^{24}$ - the welfare implications of the failure to achieve more rapid and sustained output growth start to become clear.

\section{Grain Extraction and Its Impact on Farmers in China}

Its extraordinarily erratic nature is one of the more arresting features of economic development in the People's Republic under the leadership of Mao Zedong. However, a constant throughout the period was the commitment to industrialization, ${ }^{25}$ and agriculture's contribution was fundamental. The goal would be jeopardized unless

23. From $111.83 \mathrm{~m}$ ha (1957) to $99.39 \mathrm{~m}$ ha (1976) - a decline of over $11 \%$ according to $50 N N Y Z L$, p. 21 (though these figures take no account of the retrospective need for upward revision of arable area data, highlighted in China's First (1997) National Agricultural Census.

24. A benchmark figure at the higher end of this range is applicable to rural China throughout the Mao years. Authoritative Chinese sources (incl. Chen Yun) confirm this. See K.R. Walker, Food Grain Procurement and Consumption in China (Cambridge: Cambridge University Press, 1984), p. 3.

25. "The stark contrast in productivity between industry and agriculture reflects the consistent concentration of investment resources in the former over many years in search of maximum industrial growth" (Y.Y. Kueh, "China's new industrialization strategy," The China Quarterly, No. 119 (1989), p. 422. 
an agricultural surplus ${ }^{26}$ could be generated and made available to the government. Despite being poor, China's agriculture even before 1949 was probably capable of generating a potentially significant surplus, captured in the shares of farm output marketed and remitted as rent. Increasing that surplus was of course a major policy goal of the government after 1949. But an even greater concern was the need to secure control over the available supply of farm products (above all, grain). The importance of extraction was no doubt impressed upon Chinese leaders by the experience of the Soviet Union. Stalin's decision to launch collectivization at the end of the 1920s had, after all, been prompted by concerns about how to control grain supplies, and the movement had begun with a grain procurement campaign. It is no coincidence that the Chinese government's monopoly procurement and distribution - Central Purchase and Central Supply (tonggou tongxiao 统购統銷) - system was introduced in November 1953 against the background of an increasingly serious grain deficit resulting from a rapid rise in demand. ${ }^{27}$ Nor is it coincidental that Mao's advocacy, in July 1955, of accelerated co-operativization took place against the background of a loss of control over grain supplies. ${ }^{28}$

\section{National Trends}

The following analysis attempts to measure the procurement burden that was placed on Chinese farmers during the Mao era, and to consider its implications for their welfare, measured in terms of grain consumption. ${ }^{29}$ Table 3 sets out estimates of grain procurement for every year between 1953 and 1976, with allowance made for resales to farmers. The figures are given in terms of raw grain. Table 4 shows the extraction burden (for convenience, I have averaged the figures for each sub-period, although data for each of the famine years are also shown individually).

A comparison between grain procurement in China and in the Soviet Union during their FFYPs provides a telling indication of the

26. The particular emphasis on heavy industrialization meant that the role of agriculture as a source of labour was less important.

27. Unwilling either to sanction a slower rate of industrial growth or to let grain prices rise, the government opted for the introduction of compulsory quotas. The locus classicus for consideration of the rationale of the CPCS system remains Dwight $\mathrm{H}$. Perkins, Market Control and Planning in Communist China (Cambridge, MA: Harvard University Press, 1965).

28. The supposed benefits of co-operatives extended beyond tighter control over farm output to the ability to dictate the allocation of sown area between different crops and planting methods. The essential basis of the Marxist belief in the need to nurture a socialist agriculture through collectivization lay in the perceived benefits of the large scale in farm production.

29. At the low levels of per capita income that prevailed throughout the Mao period, food consumption offers the best proxy for living standards of the subsisting population. The focus on grain reflects the fact that the rural diet was dominated by the direct ingestion of grain (cereals, coarse grains [incl. potatoes] and beans). 
Table 3: Grain Production and Procurement, and Rural Grain Supplies

\begin{tabular}{|c|c|c|c|c|c|}
\hline & $\begin{array}{c}\text { Total grain } \\
\text { output } \\
\text { ( } m \text { tons })\end{array}$ & $\begin{array}{c}n \quad \text { Gross } \\
\text { procurement } \\
\text { (m tons })\end{array}$ & $\begin{array}{c}\text { Grain } \\
\text { re-sales } \\
\text { to farmers } \\
(m \text { tons })\end{array}$ & $\begin{array}{c}\text { Net } \\
\text { procurement } \\
(m \text { tons })\end{array}$ & $\begin{array}{l}\text { Rural grain } \\
t \quad \text { supplies } \\
\text { ( } m \text { tons })\end{array}$ \\
\hline \multicolumn{6}{|c|}{ First Five-Year Plan } \\
\hline 1953 & 166.83 & 47.46 & 11.58 & 35.88 & 130.95 \\
\hline 1954 & 169.52 & 51.81 & 20.23 & 31.58 & 137.94 \\
\hline 1955 & 183.94 & 50.75 & 14.57 & 36.18 & 147.76 \\
\hline 1956 & 192.75 & 45.44 & 16.74 & 28.70 & 164.05 \\
\hline 1957 & 195.05 & 48.04 & 14.17 & 33.87 & 161.18 \\
\hline \multicolumn{6}{|c|}{ Great Leap Forward } \\
\hline 1958 & 197.65 & 58.76 & 17.04 & 41.72 & 155.93 \\
\hline 1959 & 169.68 & 67.41 & 19.84 & 47.57 & 122.11 \\
\hline 1960 & 143.85 & 51.05 & 20.16 & 30.89 & 112.96 \\
\hline 1961 & 136.50 & 40.47 & 14.67 & 25.80 & 110.70 \\
\hline 1962 & 154.41 & 38.15 & 12.43 & 25.72 & 128.69 \\
\hline \multicolumn{6}{|c|}{ Recovery } \\
\hline 1963 & 170.00 & 43.97 & 13.34 & 30.63 & 139.37 \\
\hline 1964 & 187.50 & 47.43 & 15.58 & 31.85 & 155.65 \\
\hline 1965 & 194.53 & 48.68 & 15.09 & 33.59 & 160.94 \\
\hline \multicolumn{6}{|c|}{ Third Five-Year Plan } \\
\hline 1966 & 214.00 & 51.58 & 13.34 & 38.24 & 175.76 \\
\hline 1967 & 217.82 & 49.36 & 11.62 & 37.74 & 180.08 \\
\hline 1968 & 209.06 & 48.70 & 10.83 & 37.87 & 171.19 \\
\hline 1969 & 210.97 & 46.68 & 12.85 & 33.83 & 177.14 \\
\hline 1970 & 239.96 & 54.44 & 12.42 & 42.02 & 197.94 \\
\hline \multicolumn{6}{|c|}{ Fourth Five-Year } \\
\hline \multicolumn{6}{|c|}{ Plan } \\
\hline 1971 & 250.14 & 53.02 & 13.20 & 39.82 & 210.32 \\
\hline 1972 & 240.48 & 48.30 & 14.38 & 33.92 & 206.56 \\
\hline 1973 & 264.94 & 56.12 & 15.12 & 41.00 & 223.94 \\
\hline 1974 & 275.27 & 58.07 & 14.10 & 43.97 & 231.30 \\
\hline 1975 & 284.52 & 60.86 & 16.92 & 43.94 & 240.58 \\
\hline 1976 & 286.31 & 58.25 & 17.53 & 40.72 & 245.59 \\
\hline
\end{tabular}

Source:

50NYTJZL, p. 37 (output); Ministry of Agriculture, Planning Office, Nongye jingji ziliao, 1949-83 (Materials on the Agricultural Economy, 1949-83), hereafter NYJJZL, pp. 342-43 (procurement and re-sales). No date of publication is given in the copy of the document available to me, but it is likely to have been 1984 .

heavy burden carried by Chinese farmers. Under the Soviet First Plan (1928-32), which coincided with the first great collectivization drive, ${ }^{30}$ state procurement of grain absorbed 24.7 per cent of total production.

30. Between 1928 and 1932 the proportion of peasant households in collectives (kolkhozy) rose from $1.7 \%$ to $61.5 \%$. Lynne Viola, Peasant Rebels under Stalin: Collectivization and the Culture of Peasant Resistance (New York \& Oxford: Oxford University Press, 1996), p. 211. 
Table 4: The Burden of Grain Extraction on Chinese Farmers

\begin{tabular}{|c|c|c|c|c|c|}
\hline & $\begin{array}{l}\text { Total } \\
\text { grain } \\
\text { output }\end{array}$ & $\begin{array}{c}\text { Gross } \\
\text { procurement }\end{array}$ & $\begin{array}{c}\text { Grain } \\
\text { re-sales to } \\
\text { farmers }\end{array}$ & $\begin{array}{c}\text { Net } \\
\text { procurement }\end{array}$ & $\begin{array}{c}\text { Rural } \\
\text { grain } \\
\text { supplies }\end{array}$ \\
\hline & \multicolumn{5}{|c|}{$\begin{array}{l}\text { All output and procurement figures in } m \text { tons of raw grain. } \\
\text { Figures in brackets show procurement and re-sales as } \% \text { of total output. }\end{array}$} \\
\hline $\begin{array}{l}\text { First Five- } \\
\text { Year Plan }\end{array}$ & 181.62 & 48.70 & 15.46 & 33.24 & 148.38 \\
\hline (1953-57 av) & $(100.00)$ & $(26.81)$ & $(8.51)$ & $(18.30)$ & $(81.70)$ \\
\hline $\begin{array}{l}\text { Great Leap } \\
\text { Forward }\end{array}$ & 160.42 & 51.17 & 16.83 & 34.34 & 126.08 \\
\hline (1958-62 av) & $(100.00)$ & $(31.90)$ & (10.49) & (21.41) & $(78.59)$ \\
\hline 1959 & $\begin{array}{c}169.68 \\
(100.00)\end{array}$ & $\begin{array}{c}67.41 \\
(39.73)\end{array}$ & $\begin{array}{c}19.84 \\
(11.69)\end{array}$ & $\begin{array}{c}47.57 \\
(28.04)\end{array}$ & $\begin{array}{l}122.11 \\
(71.96)\end{array}$ \\
\hline 1960 & $\begin{array}{c}143.85 \\
(100.00)\end{array}$ & $\begin{array}{c}51.05 \\
(35.49)\end{array}$ & $\begin{array}{c}20.16 \\
(14.01)\end{array}$ & $\begin{array}{c}30.89 \\
(21.47)\end{array}$ & $\begin{array}{l}112.96 \\
(78.53)\end{array}$ \\
\hline 1961 & $\begin{array}{c}136.50 \\
(100.00)\end{array}$ & $\begin{array}{c}40.47 \\
(29.65)\end{array}$ & $\begin{array}{l}14.67 \\
(9.11)\end{array}$ & $\begin{array}{c}25.80 \\
(18.84)\end{array}$ & $\begin{array}{l}110.70 \\
(81.10)\end{array}$ \\
\hline $\begin{array}{l}\text { Recovery } \\
\text { years }\end{array}$ & 184.01 & 46.69 & 14.67 & 32.02 & 151.99 \\
\hline (1963-65 av) & $(100.00)$ & $(25.38)$ & (7.97) & (17.40) & $(82.60)$ \\
\hline $\begin{array}{l}\text { Third Five- } \\
\text { Year Plan }\end{array}$ & 218.36 & 50.15 & 12.21 & 37.94 & 180.42 \\
\hline (1966-79 av) & $(100.00)$ & $(22.97)$ & $(5.59)$ & (17.37) & $(82.63)$ \\
\hline $\begin{array}{l}\text { Fourth } \\
\text { Five-Year } \\
\text { Plan }\end{array}$ & 263.07 & 55.27 & 14.74 & 40.53 & 222.54 \\
\hline (1971-75 av) & $(100.00)$ & (21.01) & $(5.60)$ & (15.41) & (84.59) \\
\hline 1976 & $\begin{array}{c}286.31 \\
(100.00)\end{array}$ & $\begin{array}{c}58.25 \\
(20.35)\end{array}$ & $\begin{array}{l}17.53 \\
(6.12)\end{array}$ & $\begin{array}{c}40.72 \\
(14.22)\end{array}$ & $\begin{array}{c}245.59 \\
(85.78)\end{array}$ \\
\hline
\end{tabular}

Source:

Table 3.

The corresponding Chinese figure (26.8 per cent) was higher, despite the fact that average per capita grain output in China was more than 40 per cent lower than in the Soviet Union. ${ }^{31}$

With average per capita grain output not significantly above subsistence level, farm conditions in China could not sustain such a high procurement ratio. So much is clear from Table 4, which shows that, on average, more than 18 million tons a year were returned to

31. I estimate average per capita grain production (excl. potatoes) in 1930 in the USSR to have been about $530 \mathrm{~kg}$ (output from ibid. p. 232, Table 23; total population from Jerzy F. Karcz, The Economics of Communist Agriculture: Selected Papers (Bloomington: International Development Institute, 1979), p. 479). In China in 1955 also the mid-point of its FFYP and a bumper harvest year - the corresponding figure was about $300 \mathrm{~kg}$. 
the rural sector in order to maintain adequate nutritional standards there. As a result, China's net procurement ratio was significantly lower than the gross ratio. ${ }^{32}$

The most striking feature of the two tables is the remarkable increase in the burden of extraction that occurred during the Great Leap Forward. As it happens, the procurement ratio in the USSR also rose sharply in its Second FYP period (1933-37). ${ }^{33}$ But whereas the famine that took place in the wake of the increasing procurement burden in the USSR (especially the Ukraine) reflected a knowing wilfulness on the part of Stalin, famine conditions in China - in terms of their impact on human life, far more serious than in the Soviet Union - had their origin in misguided extraction policies based on serious misinformation about the true level of the grain harvest in $1958 .{ }^{34}$ As shown below, raising the procurement ratio to new heights while total grain output was falling sharply was to have disastrous consequences for farmers' nutritional standards. Meanwhile, the misguided nature of such policies is also highlighted in trends in China's grain trade during these years. In 1959 and 1960, when total output had fallen by 53.8 million tons, China remained a net exporter of grain to the tune of 6.81 million tons; only in 1961 - by which time the output decline had risen to 61.2 million tons - did China revert to being a net grain importer. ${ }^{35}$

Reference was made above to the adoption of an "agriculture first" strategy in the early 1960s. The pragmatism inherent in this new stance of associated policies was reflected in procurement quota adjustments. Despite the food security concerns, the Cultural Revolution decade saw a small but steady decline in both gross and net grain procurement ratios. Throughout the period under consideration here, China's rural population continued to rise quite rapidly. With this in mind, Table 5 seeks to investigate the welfare implications - here defined in terms of food supplies - of the data presented in Tables 3 and 4.

On the basis of a self-sufficiency norm of $275-300 \mathrm{~kg}$ of raw grain per head, ${ }^{36}$ grain production was sufficient to meet the basic requirements of the Chinese population - though barely adequately - during the periods of the First and Fourth FYPs. Between 1959 and 1970, even this most basic criterion could not be fulfilled. Except for 1960-63, however, domestic output would readily have accommodated the needs of the rural population throughout the period. In fact, as the figures in the final column show, only during the last few years

32. Concealed in the figures shown in Tables 3 and 4 was a complex pattern of interprovincial grain transfers from surplus to deficit regions. This is analysed in great detail, at least for 1953-57, in Walker, Food Grain Procurement and Consumption, ch.

33. To 37.7\% (excl. potatoes) (Viola, Peasant Rebels Under Stalin, p. 250, Table 27).

34. Whether or not the worst consequences of the famine would have been avoided had the confrontation between Mao and Peng Dehuai at the Lushan Conference (July 1959) not occurred is a tantalizing question.

35. In 1961 China imported $4.45 \mathrm{~m}$ tons (net) (see Dachuan, pp. 520 and 534).

36. See above, p. 9 . The $300 \mathrm{~kg}$ figure would have been sufficient at prevailing low levels of income to provide for basic human food consumption needs, as well as leaving a small surplus for seed and livestock feed. 
Table 5: Per Capita Availability of Grain in the Rural Sector

\begin{tabular}{|c|c|c|c|c|}
\hline & \multicolumn{2}{|c|}{$\begin{array}{l}\text { Average per capita } \\
\text { output of grain }(\mathrm{kg})\end{array}$} & \multirow{2}{*}{$\begin{array}{l}\text { Average potential } \\
\text { forfeiture of } \\
\text { grain to rural } \\
\text { population as } \\
\text { result of } \\
\text { procurement } \\
\text { (net procurement } \\
\text { divided by rural } \\
\text { population) } \\
(\mathrm{kg})\end{array}$} & \multirow{2}{*}{$\begin{array}{l}\text { Average } \\
\text { availability of } \\
\text { grain after } \\
\text { re-sales (total } \\
\text { output less gros } \\
\text { procurement } \\
\text { plus re-sales) } \\
\text { per head of } \\
\text { rural population } \\
\text { ( } \mathrm{kg} \text { ) }\end{array}$} \\
\hline & $\begin{array}{c}\text { Total } \\
\text { population }\end{array}$ & $\begin{array}{c}\text { Rural } \\
\text { population }\end{array}$ & & \\
\hline \multicolumn{5}{|c|}{ First-Five Year Plan } \\
\hline 1953 & 283.74 & 333.21 & 71.66 & 261.55 \\
\hline 1954 & 281.29 & 332.15 & 61.88 & 270.25 \\
\hline 1955 & 299.26 & 352.85 & 69.40 & 283.45 \\
\hline 1956 & 306.79 & 364.88 & 54.33 & 310.55 \\
\hline 1957 & 301.69 & 361.00 & 62.68 & 298.32 \\
\hline $1953-57$ av & 294.83 & 349.14 & 63.90 & 285.24 \\
\hline \multicolumn{5}{|c|}{ Great Leap Forward } \\
\hline 1958 & 299.50 & 367.49 & 77.57 & 289.92 \\
\hline 1959 & 252.47 & 316.33 & 88.68 & 227.65 \\
\hline 1960 & 217.27 & 274.13 & 58.87 & 215.26 \\
\hline 1961 & 207.26 & 255.41 & 48.27 & 207.13 \\
\hline 1962 & 229.45 & 275.61 & 45.91 & 229.71 \\
\hline $1958-62$ av & 241.19 & 297.77 & 63.74 & 234.03 \\
\hline \multicolumn{5}{|l|}{ Recovery } \\
\hline 1963 & 245.76 & 295.20 & 53.19 & 242.01 \\
\hline 1964 & 265.96 & 318.76 & 54.15 & 264.61 \\
\hline 1965 & 268.18 & 321.98 & 55.60 & 266.39 \\
\hline $1963-65$ av & 260.14 & 312.19 & 54.30 & 257.86 \\
\hline \multicolumn{5}{|c|}{ Third-Five Year } \\
\hline \multicolumn{5}{|c|}{ Plan } \\
\hline 1966 & 287.09 & 344.04 & 61.48 & 282.56 \\
\hline 1967 & 285.22 & 341.78 & 59.22 & 282.56 \\
\hline 1968 & 266.20 & 316.85 & 57.40 & 259.46 \\
\hline 1969 & 261.52 & 309.03 & 49.55 & 259.48 \\
\hline 1970 & 289.14 & 341.18 & 59.75 & 281.44 \\
\hline $1966-70$ av & 277.74 & 330.34 & 57.40 & 272.94 \\
\hline \multicolumn{5}{|c|}{ Fourth Five-Year } \\
\hline \multicolumn{5}{|c|}{ Plan } \\
\hline 1971 & 293.49 & 348.00 & 55.40 & 292.60 \\
\hline 1972 & 275.85 & 326.98 & 46.12 & 280.86 \\
\hline 1973 & 296.98 & 352.22 & 54.51 & 297.72 \\
\hline 1974 & 302.96 & 358.52 & 57.27 & 301.25 \\
\hline 1975 & 307.86 & 364.11 & 56.23 & 307.88 \\
\hline $1971-75$ av & 295.65 & 350.23 & 53.96 & 296.27 \\
\hline 1976 & 305.50 & 361.50 & 51.41 & 310.09 \\
\hline
\end{tabular}

Sources:

Table 4; 50NTJZL, p.1 (total and rural population). 
of Mao's life did per capita grain supplies to the rural population fulfil the $300 \mathrm{~kg}$ norm. From this perspective, one way of interpreting the net procurement estimates shown in the penultimate column of Table 3 would be to regard them as a crude proxy for the import gap that would have had to be filled in order to provide for the subsistence needs of the Chinese population in the absence of the CPCS system. ${ }^{37}$

On the basis of Piazza's study of food consumption and nutrition at the level of total population, ${ }^{38}$ Table 6 attempts to estimate average daily energy intake for China's rural population. These are no more than proxy indicators, but they offer a sufficiently robust basis on

37. I stress the crude nature of this argument, which takes no account, for example, of food supplies available to rural households from private plots or concealed land sown under grain, or from diverting feed and seed supplies to human consumption. The implications of the decline in grain production in the aftermath of the Great Leap Forward emerge clearly from the data. It is possible, for example, to compare actual rural grain availability with the volume of grain that would have been required to provide for China's rural population:

\begin{tabular}{cccc}
\hline & $\begin{array}{c}\text { Projected rural } \\
\text { grain needs } \\
(m \text { tons })\end{array}$ & $\begin{array}{c}\text { Actual rural } \\
\text { grain supplies } \\
(m \text { tons })\end{array}$ & $\begin{array}{c}\text { Grain surplus }(+) \\
\text { deficit }(-) \\
\text { ( } m \text { tons) }\end{array}$ \\
1958 & 161.35 & 155.93 & +9.26 \\
1959 & 160.92 & 122.11 & -38.81 \\
1960 & 157.43 & 112.96 & -44.47 \\
1961 & 160.33 & 110.70 & -49.63 \\
\hline
\end{tabular}

An even bigger gap between availability and needs would emerge if we were to project a revised population series based on average rural population growth during 1953-57 (i.e. $1.9 \%$ p.a.). Alternatively, one might compare the number of peasants that could, ceteris paribus, have been supported ("potential subsisting population") by the output levels of 1959-61 with the number that production in fact sought to provide for ("actual subsisting population"):

\begin{tabular}{cccc}
\hline & $\begin{array}{c}\text { Potential subsisting } \\
\text { population }(m)\end{array}$ & $\begin{array}{c}\text { Actual subsisting } \\
\text { population }(m)\end{array}$ & $\begin{array}{c}\text { Difference } \\
(m)\end{array}$ \\
1958 & 658.83 & 537.84 & 120.99 \\
1959 & 565.60 & 536.40 & 29.20 \\
1960 & 479.50 & 524.76 & -45.26 \\
1961 & 455.00 & 534.44 & -79.44 \\
\hline
\end{tabular}

These estimates are purely hypothetical. But they intimate the enormity of the food security threat inherent in mismanagement of the Great Leap Forward. In the event, the apocalypse suggested in the figures did not happen, although the finding that up to 30 million excess deaths occurred during 1959-61 leaves no doubt as to the unprecedented scale of the drama that unfolded. Note too that in addition to $30 \mathrm{~m}$ excess deaths, declining sexual activity and the effects of "amenorrhea of hunger" (the failure to menstruate by women of childbearing age) caused a "birth deficit" of a further $30 \mathrm{~m}$ babies who otherwise would have been born.

38. Alan Piazza, Food Consumption and Nutritional Status in the PRC (Boulder, CO: Westview Press, 1986). 
Table 6: Estimated Energy Intake Among the Rural Population

\begin{tabular}{|c|c|c|c|c|}
\hline & $\begin{array}{c}\text { Average rural } \\
\text { per capita } \\
\text { grain } \\
\text { production } \\
\quad(\mathrm{kg})\end{array}$ & $\begin{array}{c}\text { Average rural } \\
\text { daily per } \\
\text { capita energy } \\
\text { intake } \\
\text { (Kcal) }\end{array}$ & $\begin{array}{l}\text { Average rural } \\
\text { daily per } \\
\text { capita energy } \\
\text { requirements } \\
\quad \text { (Kcal })\end{array}$ & $\begin{array}{l}\text { Intake } \\
\text { as \% of } \\
\text { requirements }\end{array}$ \\
\hline $\begin{array}{l}\text { First Five-Year Plan } \\
(1953-57 \mathrm{av})\end{array}$ & 285.24 & 2,119 & 2,092 & 101.3 \\
\hline $\begin{array}{l}\text { Great Leap Forward } \\
(1958-62 \mathrm{av})\end{array}$ & 234.03 & 1,779 & 2,116 & 84.1 \\
\hline 1959 & 227.65 & 1,668 & 2,111 & 79.0 \\
\hline 1960 & 215.26 & 1,587 & 2,116 & 75.0 \\
\hline 1961 & 207.13 & 1,644 & 2,121 & 77.5 \\
\hline Recovery (1963-65 av) & 257.86 & 1,939 & 2,135 & 90.8 \\
\hline $\begin{array}{l}\text { Third Five-Year Plan } \\
(1966-70 \mathrm{av})\end{array}$ & 272.94 & 2,020 & 2,149 & 94.0 \\
\hline $\begin{array}{l}\text { Fourth Five-Year } \\
\text { Plan (1971-75 av) }\end{array}$ & 296.27 & 2,157 & 2,172 & 99.3 \\
\hline 1976 & 310.09 & 2,257 & 2,203 & 102.5 \\
\hline
\end{tabular}

Notes and Sources:

I have estimated rural energy intake on the basis of output:energy conversion ratios derived from annual estimates in Alan Piazza, Food Consumption and Nutritional Status in the PRC (Boulder, CO: Westview Press, 1986), p. 77, Table 4.3. Energy requirements are those shown by ibid. p. 92, Table 4.8. Rural per capita grain production from Table 5 .

which to draw two conclusions. The first is to reinforce the severity of the rural food crisis in the wake of the Great Leap Forward. The second is to highlight the closeness to the margin of subsistence in which Chinese peasants lived throughout the Mao era. Viewed from the national level, not only was there no appreciable improvement in food consumption during the period, but only in its final years did standards re-attain the level of the FFYP years. ${ }^{39}$

\section{Regional Trends}

A shortcoming of the foregoing analysis is that it takes no account of regional variations in rural conditions. The need to consider the 27 provinces "proper" 40 makes a detailed analysis of provincial trends in grain output, extraction and rural consumption impossible within this short section. Nevertheless, the estimates presented here are derived

39. In physical terms, only in the very year of Mao's death (1976) did per capita grain supplies to the rural population finally re-attain the previous peak level of 1956 . But per capita energy supplies in 1976 were probably still lower than in 1956.

40. I.e. excluding the three municipalities with provincial-level status (Beijing, Tianjin and Shanghai). Data for Tibet are also excluded. In referring to "provinces" I also mean to include the autonomous regions. 
from an exhaustive statistical analysis of the total and per capita output, procurement (gross and net) and residual agricultural supply of grain in every province for every year between 1953 and $1976 .{ }^{41}$

The egalitarian thrust of the Maoist development strategy did not prevent the persistence of wide inter and intra-regional differences in rural economic and welfare conditions. Widely differing inter-regional levels of population and farm productivity dictated the need for a complex nexus of grain transfers between surplus and deficit provinces, which was reflected in major differences in provincial net procurement ratios. Such differences were, however, far from stable, causing the regional profile of grain transfers to change quite significantly during the Mao era.

Table A1 in Appendix A sets out comprehensive time-series data relating to total output, net procurement and residual supplies of grain available to the farm population in every province of China between 1953 and 1975. From these figures I have derived summary estimates for each of seven regions, shown in Table 7. A common, although not universally consistent, pattern emerges from these figures (see Figure 1). Throughout the Mao era, the highest rate of extraction was in the north-east, a reflection of large surpluses produced by Heilongjiang and, at least until the mid-1960s, Jilin. More surprising is the finding that in the 1950s, the second-highest rate of extraction was in the north-west, an inherently poor agricultural region, albeit one with a small population. This did not, however, persist, and by the second half of the 1970s, the net procurement rate had fallen below that of every other region. What also emerges is that by the end of Mao's life, in virtually every region the rate was lower than it had been in the 1950s and early 1960s. This reflects China's change of status from a net grain exporter to a net importer in and after 1960 in the wake of the food crisis precipitated by the Great Leap Forward. Allowing urban food needs - above all, those of Beijing, Tianjin and Shanghai (which accounted for 12.6 per cent of China's urban population in 1957) - to be met from overseas suppliers significantly eased the procurement burden on farmers and left them with larger amounts for subsistence, feed and seed. I return to the impact of the Leap on rural living standards below.

Changes in the rate of extraction assume meaning only when they are related to changes in output that have meanwhile occurred. That is, depending on whether total grain output has risen or fallen, a decline in the net procurement rate may generate a greater or smaller transfer of grain, in absolute terms. This is highly relevant to China's

41. For valuable insights into inter-provincial grain flows, see also Walker, Food Procurement and Consumption in China; and Thomas P. Lyons, Economic Integration and Planning in Maoist China (New York: Columbia University Press, 1987). A remarkable provincial analysis of the implications for food consumption of the Great Leap Forward is given by Walker in "Food and mortality in China during the Great Leap Forward." 


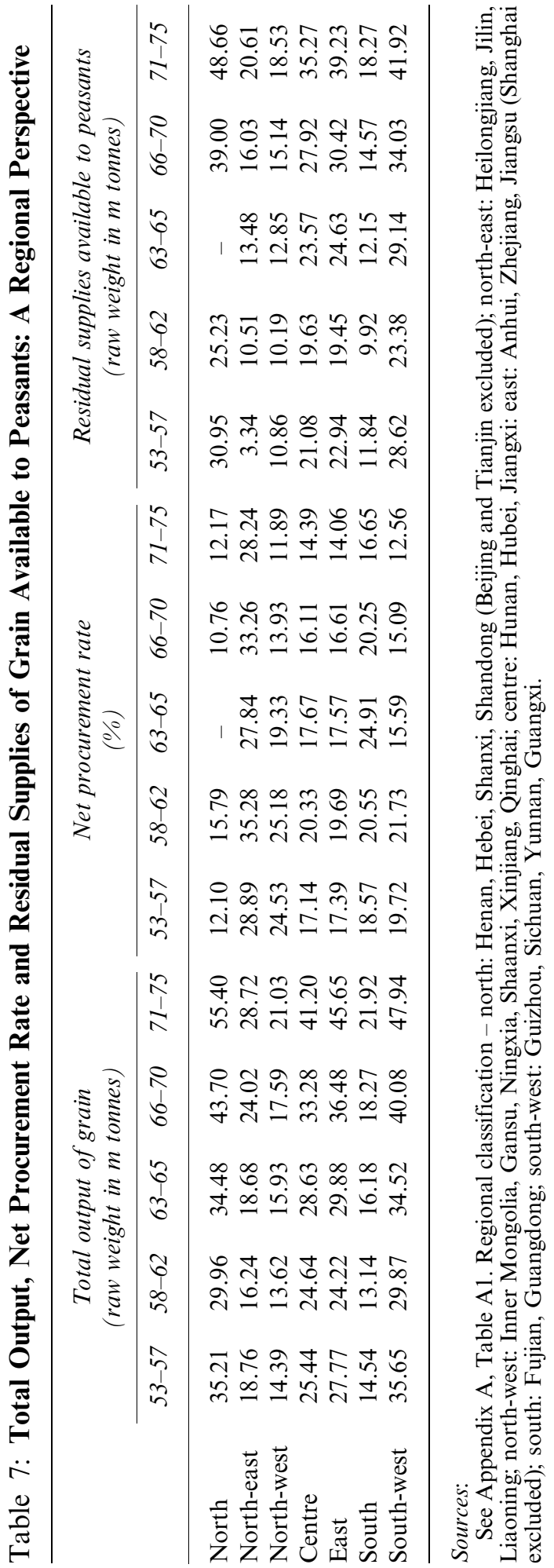


Figure 1: Net Procurement Rates

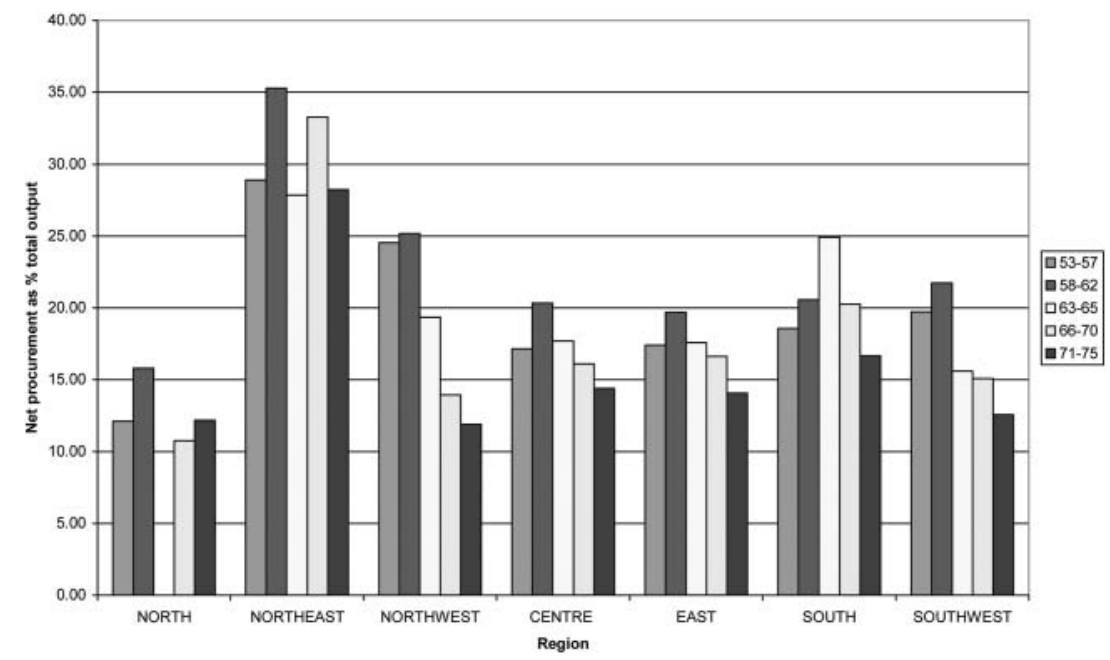

experience under planning, estimates of absolute levels of procurement showing that with two exceptions - in the south and south-west - by the first half of the 1970s, despite a fall in the net extraction rate, the amount of grain released through procurement by each region was greater than it had been in the 1950s and early 1960s.

It is a truism that the Great Leap Forward marked a watershed in China's economic performance and policy formulation, especially in regard to the agricultural sector. The trauma of the Leap is suggested in the sharp rise in both the rate and level of grain extraction that occurred after 1958 against the background of what was initially thought to have been a doubling of output in 1958. In fact, total production of grain rose only marginally in this year: the precise increase is still a matter for debate. ${ }^{42}$ Worse, in the three years that followed (1961-63), while grain output fell by $61.15 \mathrm{~m}$ tonnes - a decline of over 30 per cent - the rate of net procurement increased to an unprecedented level in almost every province (see Table 8).

Throughout the Mao era, levels of grain consumption among farmers were determined by three main factors: output growth, net procurement and population growth. It is beyond the scope of this article to consider the separate effect on consumption of each of these factors. But as a preliminary to that exercise, I have converted the aggregate data shown in Table A1 (Appendix) to estimates of average output and availability, after procurement, per head of farm

42. The most recent time-series data available to me show national grain output to have risen by a mere $1.3 \%$ in 1958 (from $195.045 \mathrm{~m}$ tones to $197.65 \mathrm{~m}$ tonnes). See NBS, Department of Comprehensive Statistics, Xin Zhongguo wushiwu nian tongji ziliao huibian (China Compendium of Statistics, 1949-2004) (Beijing: Tongji chubanshe, 2005), p. 45. 
Table 8: The Impact of the Leap on Net Procurement Rates

\begin{tabular}{lcc}
\hline & $\begin{array}{c}\text { Net procurement rate } \\
(\%), 1953-57\end{array}$ & $\begin{array}{c}\text { Net procurement rate } \\
(\%), 1959-61\end{array}$ \\
\hline Henan & 13.28 & 13.10 \\
Hebei & 3.60 & 20.55 \\
Shanxi & 19.58 & 21.63 \\
Shandong & 15.09 & 16.07 \\
Inner Mongolia & 35.70 & 35.53 \\
Gansu & 20.47 & 20.96 \\
Ningxia & 21.34 & 26.42 \\
Shaanxi & 19.20 & 22.87 \\
Xinjiang & 24.23 & 25.92 \\
Qinghai & 20.42 & 24.40 \\
Heilongjiang & 39.62 & 28.45 \\
Jilin & 34.76 & 44.08 \\
Liaoning & 11.35 & 20.90 \\
Hunan & 13.79 & 18.66 \\
Hubei & 16.09 & 19.47 \\
Jiangxi & 24.23 & 30.25 \\
Anhui & 18.41 & 19.47 \\
Zhejiang & 17.99 & 22.16 \\
Jiangsu & 16.32 & 20.94 \\
Fujian & 20.55 & 28.66 \\
Guangdong & 17.76 & 26.75 \\
Guizhou & 17.08 & 20.92 \\
Sichuan & 23.00 & 27.70 \\
Yunnan & 17.33 & 19.57 \\
Guangxi & 12.75 & 18.20 \\
\hline & & \\
\hline
\end{tabular}

Source:

NYJJZL, pp. 354-407.

population in each province (provincial details are in Table A2). The regional findings in Table 9 are derived from these provincial figures. In interpreting these figures, it should be borne in mind that in the economic circumstances of the early Mao years, 275 kilograms of raw grain provided a reasonable level of self-sufficiency among Chinese farmers. ${ }^{43}$ The left-hand side of the table reveals that except in the north, per capita output throughout the period was sufficient to meet this benchmark, and even to generate a surplus above subsistence needs (see also Figure 2). By contrast, as shown in Figure 3, the data to the right indicate that until the second half of the 1960s (and in the north and south-west even later) rural per capita availability was often

43. Walker's own chosen definition of grain self-sufficiency fell within a range of 275-309 kg (see Food Grain Procurement and Consumption, p. 3.) Note that he cites a 1955 speech by Chen Yun to the effect that $280 \mathrm{~kg}$ offered "sufficient" supplies to meet personal consumption, feed and seed needs (ibid.). 


\section{Figure 2: Average Grain Output per Head of Farm Population: A}

\section{Regional Perspective}

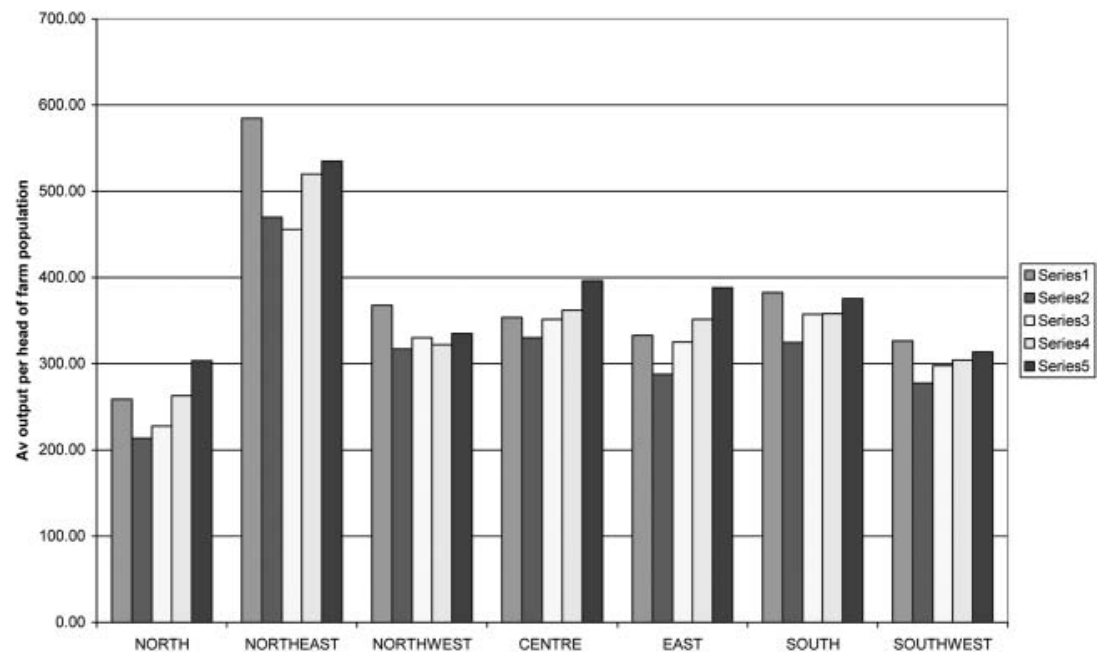

unable to meet even basic subsistence requirements. As far as I know, there is no evidence that the Chinese leadership deliberately targeted farmers in the way in which the government under Stalin did during the Soviet collectivization campaigns. ${ }^{44}$ In the USSR, re-sales to the farm sector were unknown ${ }^{45}$ and what saved many peasants from starvation in the mid-1930s was the produce available from their private plots. In China, grain re-sales to farmers were their salvation something that can easily be demonstrated by subtracting rural resales from the provincial and regional estimates of total supplies shown in Table A1. In the absence of transfers back to the villages, hunger and starvation would have been more common occurrences in many parts of China before and after the great famine of $1959-61{ }^{46}$

Nevertheless, the findings presented here do suggest that quite widespread rural impoverishment was one of the effects of the central

44. E.g. I do not think that the simple statement that "peasant terror derived from and was conditioned by state terror," which captures the reality of conditions in the Soviet countryside in the late 1920s and early 1930s, can be applied to conditions in China. The quotation is Lynne Viola's: see Peasant Rebels under Stalin, p. 130.

45. In 1941 (the first full year of war against Germany), slightly less than 5\% of compulsory deliveries and payments in kind to Machine Tractor Stations were held as food reserves and welfare supplies for orphans, invalids, etc. (ibid. p. 286). I am grateful to Colin White for his insights into the impact of collectivization on rural consumption in the Soviet Union.

46. Unfortunately, the tyranny of the word limit makes it impossible to consider, in detail, the implications for rural consumption of the Great Leap Forward. The estimates shown in Tables A1 and A2 are eloquent testimony to the enormity of the food crisis that faced the rural sector during 1959-61. E.g. it is no coincidence that the rural population of the south-west should have shown an absolute decline between 1953-57 and 1958-62 - a reflection of the catastrophic famine in Sichuan, where some $5 \mathrm{~m}$ "excess deaths" are thought to have occurred. 
Figure 3: Average Grain Availability Per Head of Farm Population: A Regional Perspective

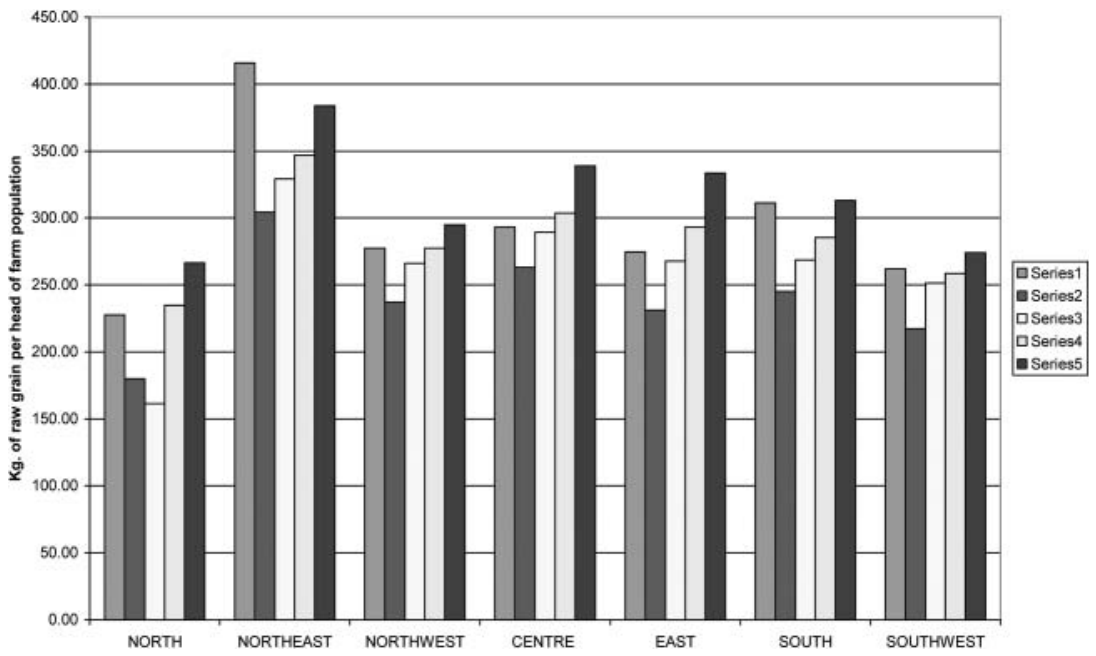

government's extractive policies - and by implication of the economic strategy of which these policies were a part. ${ }^{47}$ It is difficult to know to what extent below-subsistence average per capita grain availability actually resulted in malnourishment. The more likely immediate consequence was to reduce feed to draught animals in order to provide more for human consumption. In addition, as in the USSR, private plots were an important source of supplementary energy. ${ }^{48}$

There is a policy inference too to be drawn. Throughout the Mao era, Beijing sought to implement a forced industrialization strategy, one that placed the highest premium on maximizing heavy industrial growth. In this, agriculture had a vital facilitating role to play: most directly through the provision of cheap food (grain) for the growing urban proletariat. In fulfilling this role without recourse to overseas purchases of grain, at least until 1961 when China reverted to being a net grain importer, the farm sector minimized its claims on scarce foreign exchange. In the absence of significant farm modernization, it also minimized its claims on central budgetary funds, thereby maximizing industry's investment capacity. The achievement was in many ways a remarkable one, not least when compared with the much

47. Until the mid-1960s, the only region that enjoyed average per capita grain supplies that were comfortably in excess of subsistence was the north-east (though one or two provinces in other regions occasionally also exceeded this basic level). Interestingly, the population growth in the north-east greatly outstripped that of all other regions between 1963-65 and 1958-62: could this have reflected the desirability of the region as a refuge for hungry migrants from northern provinces?

48. In interpreting the figures in Tables 9 and A2, note that " $200 \mathrm{~kg}$ of unhusked grain, after provision for seed and some livestock feed, could provide 1,200-1,400 calories, depending on the type of grain ..." (Walker, Food Grain Procurement and Consumption, p. 3). 
greater violence and rural dislocation that had accompanied the implementation of a similar strategy in the Soviet Union. But it was not without its cost, captured most eloquently in the stagnation of farm consumption and welfare. Even allowing for increased rural grain availability, at the end of Mao's life food consumption for most farmers remained within the subsistence range. The scale of rural impoverishment that characterized China during the Mao era was ultimately unsustainable, and the failure to generate more significant improvements in farmers' living standards was an important driver of the first rural reforms of the Deng era.

Table A1 shows that the regional estimates conceal wide interprovincial variations in rural grain output and consumption. No less important are intra-provincial differences; after all, many Chinese provinces have populations to rival those of large European countries. From this perspective, the publication since the 1990s of grain "gazetteers" is an important development that has made available detailed statistical data and other information relating to grain production, procurement and distribution at county level throughout China. A few examples from these sources highlight some of the micro-level regional variations in rural living conditions associated with different net procurement burdens.

Table 10 provides indicators of per capita grain availability ${ }^{49}$ in seven counties in five Chinese provinces during the Mao era. They include counties in northern, eastern, southern and south-western regions, but given that there were more than 2,000 counties in China at the end of the 1970s, it would be silly to claim that they constitute a representative sample. What is perhaps most striking is the commonality of experience which they display (incidentally confirming the picture shown in the national figures presented earlier).

The estimates in Table 10 highlight the dramatic impact of the events of the Great Leap Forward and its immediate aftermath (195862) on China's peasants. Despite the government's imposition of tight control over grain, re-sales to the countryside through the CPCS system guaranteed adequate supplies to the rural population. Indeed, for many peasants 1956 marked an historic high point in grain consumption. But the collapse of the statistical system in 1958 presaged three years in which a savage deterioration in China's rural food security precipitated terrible famine in the countryside. Table 10 underlines the strong regional dimension of famine conditions in 1959-61, as well as differences in the chronology of the famine. Among the seven counties, average grain availability in 1961 ranged from $134 \mathrm{~kg}$ in Pucheng (Fujian) to $254 \mathrm{~kg}$ in Fangcheng (Henan), a gap wide enough to embrace severe famine in one case and adequate

49. Great care must be taken in interpreting these figures. E.g. they take no account of grain produced on farm households' private plots (although this is unlikely to have been significant in the 1950s when official policy sought to prevent farmers from growing grain on their plots). Nor can I be sure that every estimate shown is given in terms of raw, as opposed to trade, grain. 


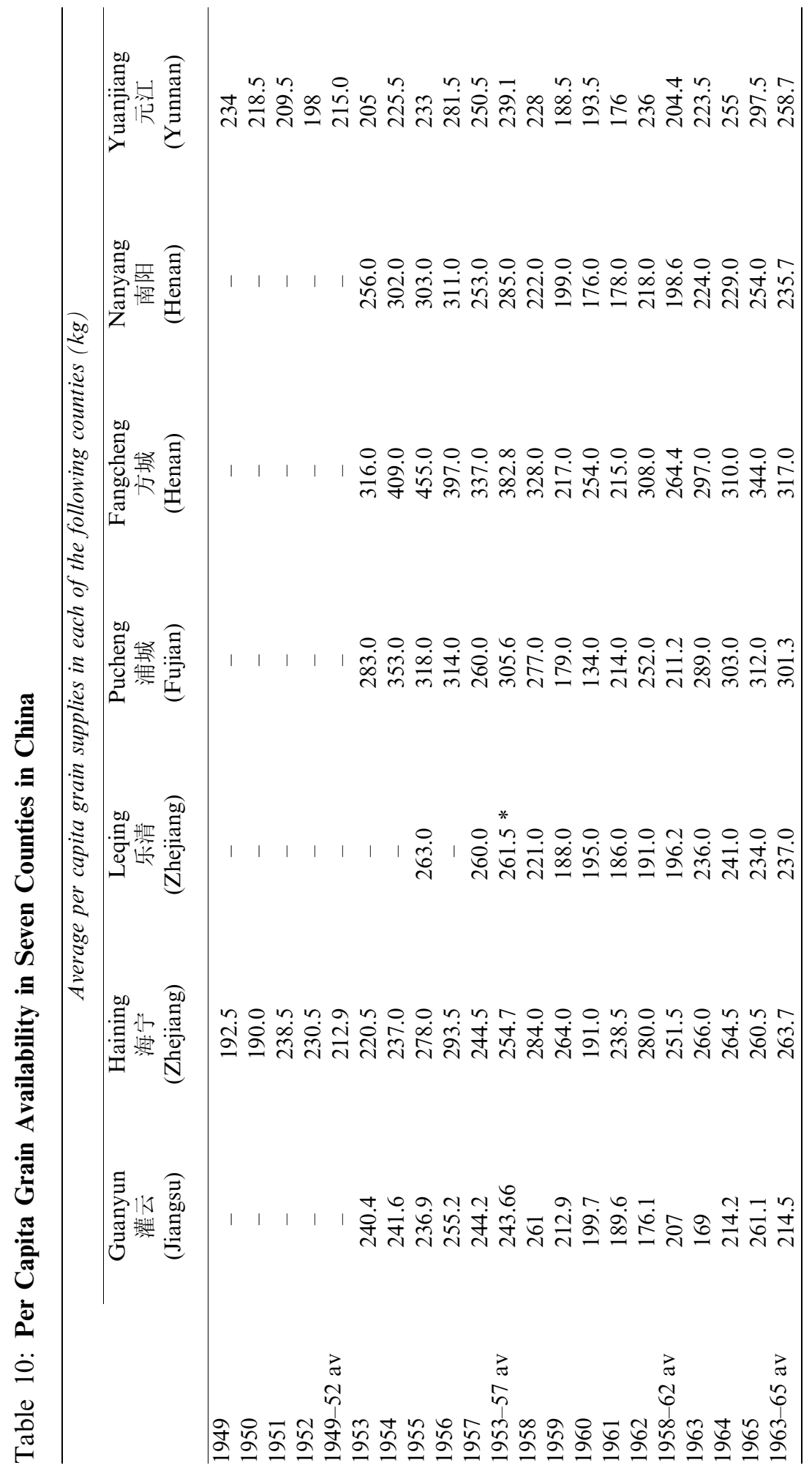




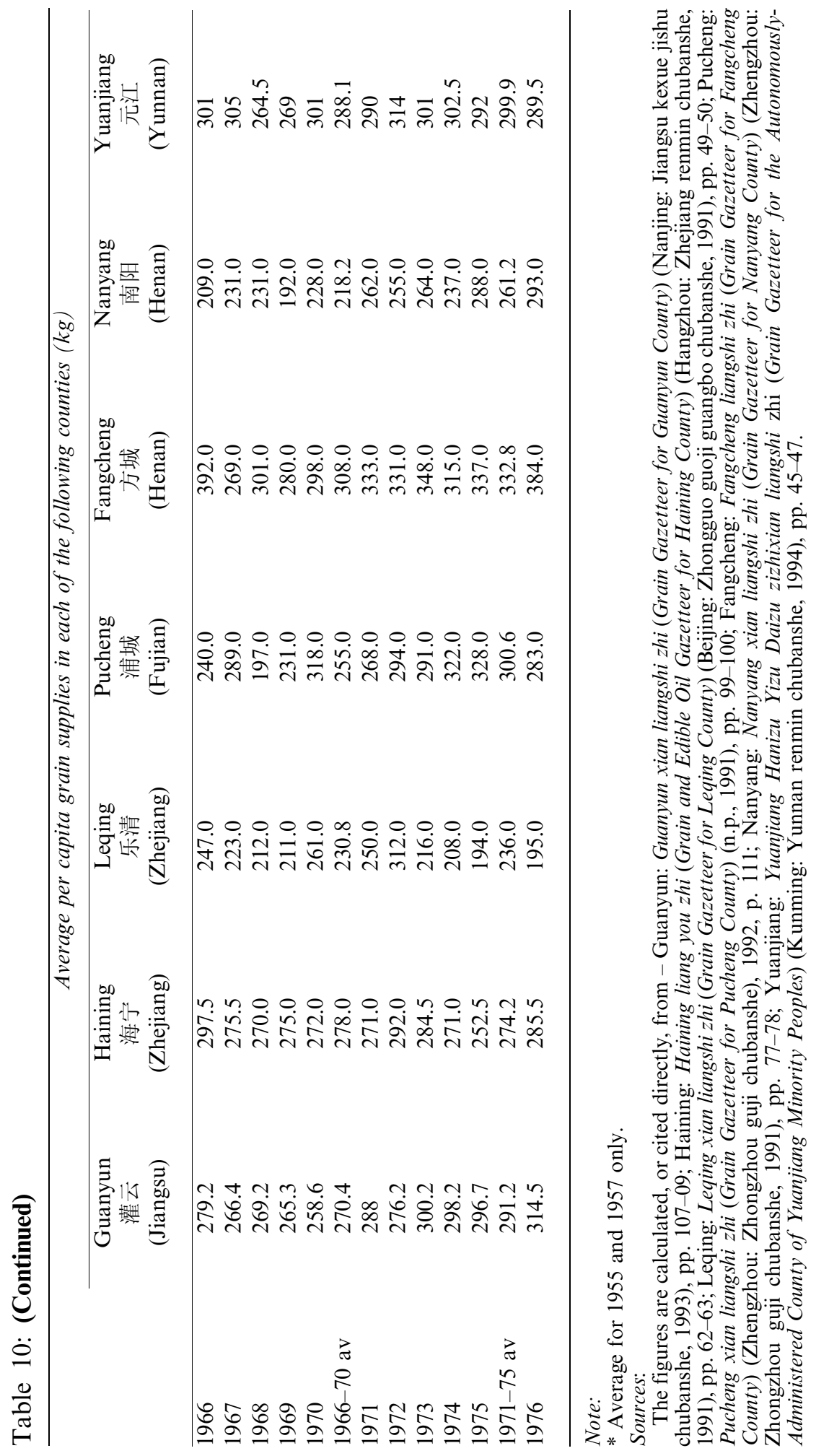


food supplies in the other. It also emerges that for some, the worst point of famine occurred in 1960, whereas for others it was in $1961 .{ }^{50}$ It is also interesting that for the two counties - Haining (Zhejiang) and Yuanjiang (Yunnan) - in which such data are available, per capita grain supplies during the Great Leap Forward fell significantly below the level of 1949 .

The county estimates throw into sharp relief the tragedy that unfolded in the Chinese countryside at the end of the 1950s and beginning of the 1960s. In Fushun in Sichuan - the worst affected of all Chinese provinces ${ }^{51}$ - sweet potatoes made up 30-50 per cent of grain supplies, while the monthly supply of fine grains (rice and/or wheat) to babies less than 12 months old was reduced to a mere $1.5 \mathrm{~kg} .{ }^{52}$ As conditions deteriorated, not only did net outflows of grain from previous surplus regions cease but national reserves were also depleted. In the first half of 1960, procurement targets from major commercial grain bases in Heilongjiang, Jilin and Sichuan were only half fulfilled; in the second half of the year supplies dried up altogether. As a result, large amounts of grain had to be sent from the state granaries to deficit regions. Within a 12-month period from the end of June 1959, central reserves fell from 17.15 million tons to 6.35 million tons. ${ }^{53}$ After 1958 grain supplies for draught animals inevitably also declined. In Guanyun (灌云) in North Jiangsu, as feed grain was reallocated to human consumption, supplies fell from 4,130 tons in 1958 to 2,080 tons in 1959 - and to a mere 440 tons in $1960 .{ }^{54}$ The impact of the decline on animals' health and survival capacity was profound.

Thanks to a revision of policy priorities, after 1961 recovery was quite rapid, although in five of the seven counties average per capita grain supplies in 1963-65 remained below the corresponding FFYP level. Thereafter, for farmers at least, the impact of the Cultural Revolution on consumption was nowhere near as serious as that of the Leap. That said, the evidence of county-level data confirms the finding of Table 5 that the Cultural Revolution's most radical and economically disruptive phase (1967-69) coincided with a renewed, albeit relatively small and short-lived, decline in rural grain availability. But although the trend growth of average per capita

50. In Guanyun the worst point was apparently reached in 1962. It would be interesting to know to what extent this experience was repeated elsewhere (i.e. beyond North Jiangsu).

51. Walker estimated that $5.952 \mathrm{~m}$ excess deaths occurred in Sichuan during 195961 ("Food and mortality," p. 109, Table 3.1).

52. Fushun County Grain Bureau, Fushun xian liangshi ju zhi (Grain Bureau Gazetteer for Fushun County) (n.p., 1988), p. 91.

53. Chu Han, Zhongguo 1959-1961: Sannian ziran zaihai (China 1959-1961: Three Years of Natural Disasters) (Chengdu: Sichuan renmin chubanshe, 1996), p. 72. The same source notes that the dislocation of normal distribution practices bringing some large cities close to exhaustion of grain supplies for their urban populations.

54. Guanyun xian liangshi zhi (Grain Gazetteer for Guanyun County) (Nanjing: Jiangsu kexue jishu chubanshe, 1993), p. 107. Each of the counties illustrated in Table 7 experienced a sharp contraction in feed supplies between 1959 and 1961. 
grain supplies was positive during the Fourth FYP period (1971-75), by the last year of Mao's life (1976) the previous peak level of grain availability had been re-attained in only three counties.

\section{Rural Diet, Income and Consumption Spending}

The most detailed source of information on rural income during the Mao period and under the impact of the early reforms is contained in the statistical survey compiled and published by the Planning Office of the Ministry of Agriculture, mentioned above, ${ }^{55}$ which provides a valuable overview of the allocation of collective income among various uses during 1956-65 and from 1970 onwards. Table 11 reproduces the relevant data. The figures show that the share of net income (minus taxes) directed to collective farm investment via the public accumulation fund rose from 4.5 per cent in 1956 - the year in which fully-socialist collectivization took place - to an astonishing 15.5 per cent in 1959. In the aftermath of the Leap, both tax and internally generated investment were curtailed, as a result of which in 1965 the public accumulation fund's income, net of tax payments, had fallen to 9 per cent. Subsequently, its burden once again increased, and in 1976 it was just over 11 per cent of net income (less taxes). By contrast, the share of the public welfare fund was much more stable and never exceeded 3 per cent of net income. More meaningfully, however, average per capita funding availability out of the public welfare fund was minimal, rising from 0.4 yuan (1956) to a peak of 2.2 yuan in 1975. Most striking of all are the figures in the final column, which highlight the very slow growth of per capita cash income: by 1.7 per cent per annum between 1956 and $1976 .^{56}$

I have already drawn attention to the downturn in agricultural growth that took place after 1958 and, more interesting, the persistence of this trend after 1965. The likelihood that this reflected the Cultural Revolution imperative of grain self-sufficiency seems to be borne out in the finding (see Table 2) that in contrast to an agricultural growth rate of 2.8 per cent per annum between 1965 and 1976 - and a mere 2.6 per cent for the cropping sector as a whole - total grain production grew by almost 3.6 per cent a year. Underlying this quite buoyant growth were steady improvements in average grain yields: from $1,626 \mathrm{~kg}$ per hectare (1965) to $2,012 \mathrm{~kg}(1970)$ and an average $2,332 \mathrm{~kg}$ (1974-76). During the same period, the sown area under grain expanded much less. In short, the increase in output was carried more by higher yields - a much more secure basis for output growth in a landscarce country like China - than by area extension. At the same time, however, the expansion of inappropriate triple-cropping of grain entailed significant economic and welfare costs in some regions. ${ }^{57}$

55. Nongye jingji ziliao 1949-1983.

56. But by $2.3 \%$ p.a., comparing $1956-58$ with $1974-76$.

57. Cf. Lardy, Agriculture in China's Modern Economic Development, p. 83. 


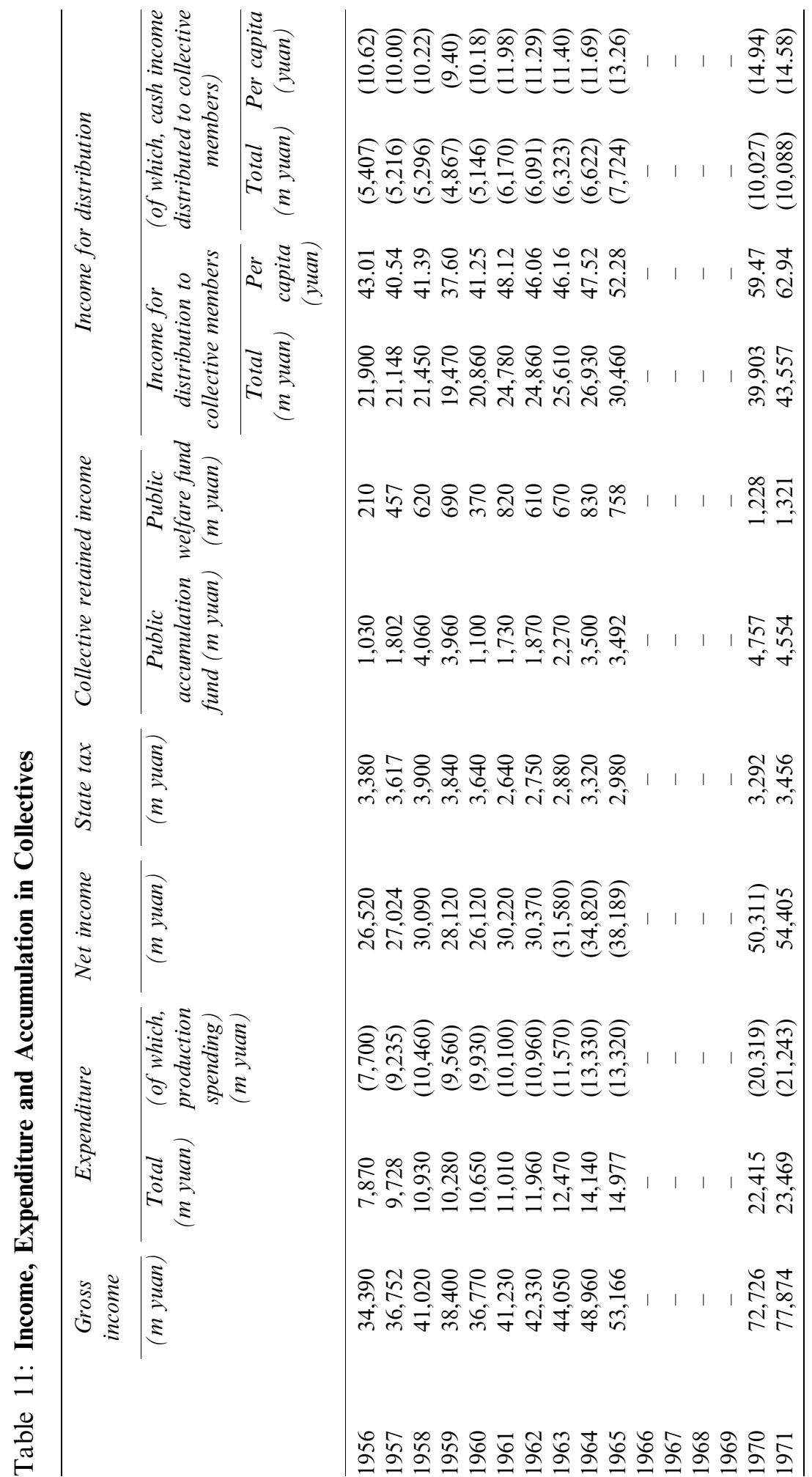




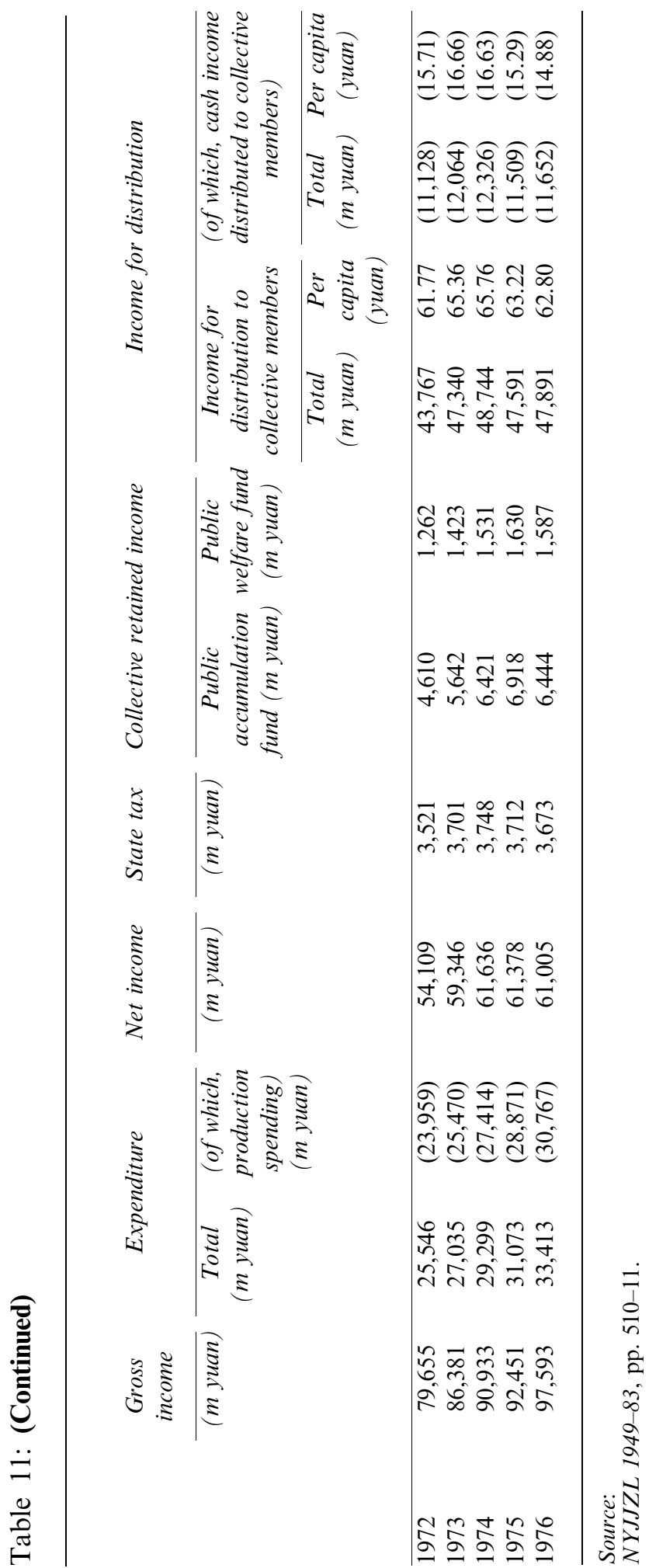


In the end, however, the most serious cost of the Cultural Revolution in the countryside was the failure to follow the dictates of the principle of comparative advantage in order to reverse the previous stagnation of farm incomes and rural living standards. ${ }^{58}$ Tables 12 and 13 seek to capture changes in material living standards by comparing average annual consumption by rural (xiangcun 乡村) residents of major farm products in 1955-57, 1963-65 and 1974-76. The corresponding figures for the urban population are also included for comparative purposes, as are those for 1981-83 in order to show the effect of early post-1978 rural reforms.

During the last three years of Mao's life, farmers' access to most basic items not only was less than during the second half of the FFYP - almost 20 years earlier - but had also fallen further behind that of their urban counterparts. In short, inter-sectoral differentials had widened. In addition, the estimates of grain consumption conceal a qualitative deterioration in the rural diet. By the end of the Mao period, peasants were consuming fewer fine grains (rice and wheat) and more coarse grains (including potatoes) than they had 20 years previously. ${ }^{59}$

The estimates in Table 12 demonstrate the dramatic effect of early post-1978 rural reforms. By the beginning of the 1980s, rural grain consumption per head had risen to a record level, had overtaken that of the urban sector and was characterized by a much higher intake of fine grains. ${ }^{60}$ Consumption of edible oil, meat and poultry, eggs, sugar and alcohol also increased sharply. ${ }^{61}$ The same picture - one of stagnation or decline between the 1950s and late 1970s but of major improvements in the wake of the first rural reforms - is shown in analysis of the structure of farm consumption spending (Table 13).

Although relevant data are not available for 1976, it is clear that in the final year of Mao's life, the pattern of consumption expenditure among the rural population was almost exactly the same as it had been in the mid-1950s and mid-1960s. Consumption spending was overwhelmingly directed towards food (which accounted for over two-thirds of total spending) and other essentials, such as clothing and fuel. When expenditure on housing was deducted, the balance left to purchase other items was minimal. By the early 1980s, the situation had already changed significantly, with food accounting for less than 60 per cent of spending and a major boom in housing under way.

58. E.g., see Liu Suinian and Wu Qungan (eds.), "Wenhua da geming" shiqi de guomin jingji (The National Economy during the period of the "Cultural Revolution") (Harbin: Heilongiiang renmin chubanshe, 1986), who refer to grain cultivation being forced on cotton and vegetable farmers (p. 38). Incomes from cotton and vegetables were significantly higher than from grain cultivation (traditionally, the lowest-return farm activity).

59. NYJJZL, pp. 548-49. The shift towards potatoes reflected their high energy yields per unit area.

60. Between 1978 and 1983, average per capita consumption of rice and wheat rose from $245.01 \mathrm{~kg}$ to $392.51 \mathrm{~kg}$ while consumption of coarse grains fell from $250.65 \mathrm{~kg}$ to $127.3 \mathrm{~kg}($ NYJJZL, p. 549).

61. Ibid. 
Table 12: Changes in Consumption in Urban and Rural China

\begin{tabular}{cccccc}
\hline \multicolumn{5}{c}{ Average per capita consumption per annum } \\
\cline { 2 - 6 } & $\begin{array}{c}\text { Food grains Vegetable oil } \\
(\mathrm{kg})\end{array}$ & $\begin{array}{c}\text { Sugar } \\
(\mathrm{kg})\end{array}$ & Pork $(\mathrm{kg})$ & $\begin{array}{c}\text { Cotton cloth } \\
\text { ("feet"*) }\end{array}$ \\
\hline China & & & & & \\
$1953-57$ & 404 & 4.8 & 2.9 & 9.8 & 22.3 \\
$1963-65$ & 353 & 2.8 & 2.9 & 10.8 & 15.4 \\
$1974-76$ & 379 & 3.4 & 4.5 & 14.6 & 23.3 \\
$1981-83$ & 451 & 7.0 & 8.5 & 23.5 & 30.6 \\
Urban & & & & & \\
$1953-57$ & 407 & 10.3 & 7.3 & 18.0 & 38.7 \\
$1964-65$ & 400 & 7.7 & 7.0 & 19.6 & 29.5 \\
$1974-76$ & 417 & 9.1 & 11.5 & 29.1 & 46.2 \\
$1981-83$ & 436 & 16.6 & 64.7 & 35.1 & 46.9 \\
Rural & & & & & \\
$1953-57$ & 403 & 3.8 & 2.1 & 8.3 & 19.5 \\
$1963-65$ & 343 & 1.8 & 2.1 & 9.0 & 12.5 \\
$1974-76$ & 372 & 2.2 & 3.2 & 11.8 & 18.9 \\
$1981-83$ & 455 & 4.7 & 6.3 & 20.8 & 26.9 \\
\hline
\end{tabular}

Note:

* That is, chi.

Source:

NYJJZL, 1949-83, pp. 538-542.

Table 13: The Changing Structure of Rural Consumption Spending in

\section{China}

Share of rural consumption spending allocated to each category (\%)

\begin{tabular}{|c|c|c|c|c|c|}
\hline \multicolumn{5}{|c|}{ Material consumption } & \multirow{2}{*}{$\begin{array}{c}\text { "Cultural" } \\
\text { and other } \\
\text { services }\end{array}$} \\
\hline Food & Clothing & Fuel & Housing & $\begin{array}{c}\text { Daily } \\
\text { articles }\end{array}$ & \\
\hline
\end{tabular}

\begin{tabular}{rrrrrrr}
\hline 1954 & 68.59 & 13.08 & 6.58 & 2.06 & 6.97 & 2.72 \\
1957 & 65.75 & 13.44 & 10.04 & 2.10 & 6.94 & 1.73 \\
1965 & 68.46 & 10.51 & 8.31 & 2.83 & 7.18 & 2.71 \\
1978 & 67.71 & 12.70 & 7.14 & 3.16 & 6.57 & 2.72 \\
1983 & 59.30 & 11.13 & 5.43 & 11.10 & 10.83 & 2.21 \\
\hline
\end{tabular}

Source:

NYJJZL, 1949-83, pp. $544-46$.

\section{Conclusion}

Two comparative perspectives highlight the deficiencies of Chinese agricultural policy during the Mao era. One is provided by China's agricultural record under the impact of the post-1978 reforms, 
especially in the early 1980s. Another is offered by the experience of agricultural development in Taiwan between the 1950s and 1970s.

Between 1928 and 1937, the economic policy options available to the Kuomintang (KMT) government on the mainland were largely determined by the nature of the base from which it derived its political support. The same can be said of the Chinese Communist Party, which relied heavily on poor tenants and landless farm workers to maintain its position in parts of rural China. This alliance was congruent with the Communist Party's ideological roots in a sense in which the KMT's reliance on landowners in the countryside was not. ${ }^{62}$ In any case, the KMT's commitment to redistributing land ownership rights and promoting farm modernization was largely formulaic. This proved to be a critical weakness, one that was exacerbated by the remoteness of senior KMT officials from the reality of socio-economic conditions in rural China. With the benefit of hindsight, the social and political consequences of the KMT government's failure to address land problems were incalculable.

The contrast between the KMT's agricultural record in China during the Nanking decade and in Taiwan between the 1950s and 1970s is an extraordinary one. In Taiwan, the implementation of a policy package that, allowing for interim agronomic and technological advances, was essentially the same as had been advocated - but never implemented - some 20 years previously, had a markedly positive and lasting impact on agricultural output and productivity growth, as well as on farmers' living standards.

But no less remarkable is the contrast on the mainland between the economic impact of the mainly one-dimensional emphasis on institutional change - that is, farm collectivization - that characterized Mao's approach to agricultural policy, and that of a more pragmatic attitude towards agricultural development that was evident after 1978. Inherent in post-1978 policies was an explicit awareness of the urgent need to raise consumption and living standards in the Chinese countryside, as well as to promote more rapid and sustained economic growth in the farm sector. This concern with the welfare aspects of agricultural growth was one that had been almost entirely lacking, except when rural conditions posed a threat to the political basis of Party rule, throughout the Mao period. ${ }^{63}$

Mao's refusal to countenance a retreat from the collectivist thrust of farm policy, except as a temporizing measure following the collapse of the Great Leap Forward, was enormously costly. Even after the events of the early 1960s, China's investment strategy remained basically unchanged. For Mao, as for Stalin, the imperative of heavy

62. The ideological thrust of some aspects of Sun Yat-sen's rural economic policy was, after all, quite radical.

63. Concern shown in recent years by the Chinese government towards san nong the problems associated with unfavourable developments in the countryside (nongcun), agriculture (nongye) and among farmers (nongmin) - also highlights worries about their social and political, more than the economic, effects. 
industrialization was a veritable shibboleth. Unlike Liu Shaoqi, Deng Xiaoping, Chen Yun and other far-sighted Chinese leaders, Mao viewed the introduction of accommodating policies towards the farm sector in the early 1960 s as a tactical expedient, not a strategic adjustment. In the event, neither in its pure nor in its modified form did the Soviet development model prove itself capable of meeting the difficult challenges confronting China's farm sector. From the 1950s to the death of Mao in 1976, Chinese agriculture failed to generate a level and pattern of growth that was capable simultaneously of raising farm productivity and efficiency, generating higher living standards for farmers, and fulfilling agriculture's developmental burden to the benefit of the entire economy and society. Such was the closeness to the margin of subsistence that throughout the Mao period, China's economy remained tied to the apron strings of the agricultural sector. Not until Mao was dead and a new ethos had emerged, grounded in an awareness of the virtues of balance, ${ }^{64}$ did agriculture cease to be a drag on economic growth and improved living standards. From this perspective, although the agricultural sector has continued to be the source of serious problems until the present day, the breaking in the early 1980s of the symbiotic link between the performance of agriculture and that of the rest of the economy must be judged one of the defining moments of China's reform era.

64. "Balance" in the sense not only of more balanced growth between economic sectors, but also of the simultaneous pursuit of economic and welfare objectives. 


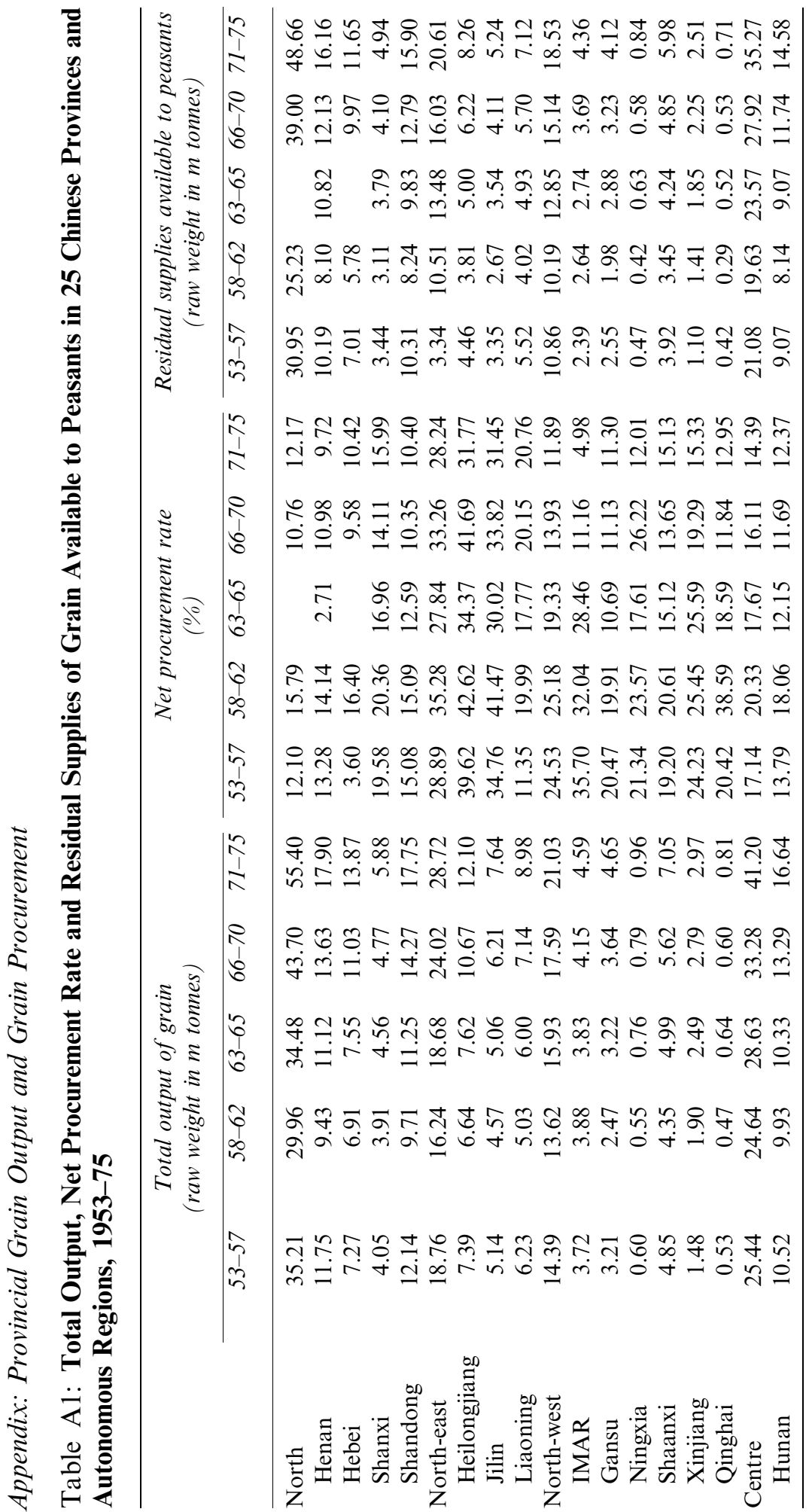




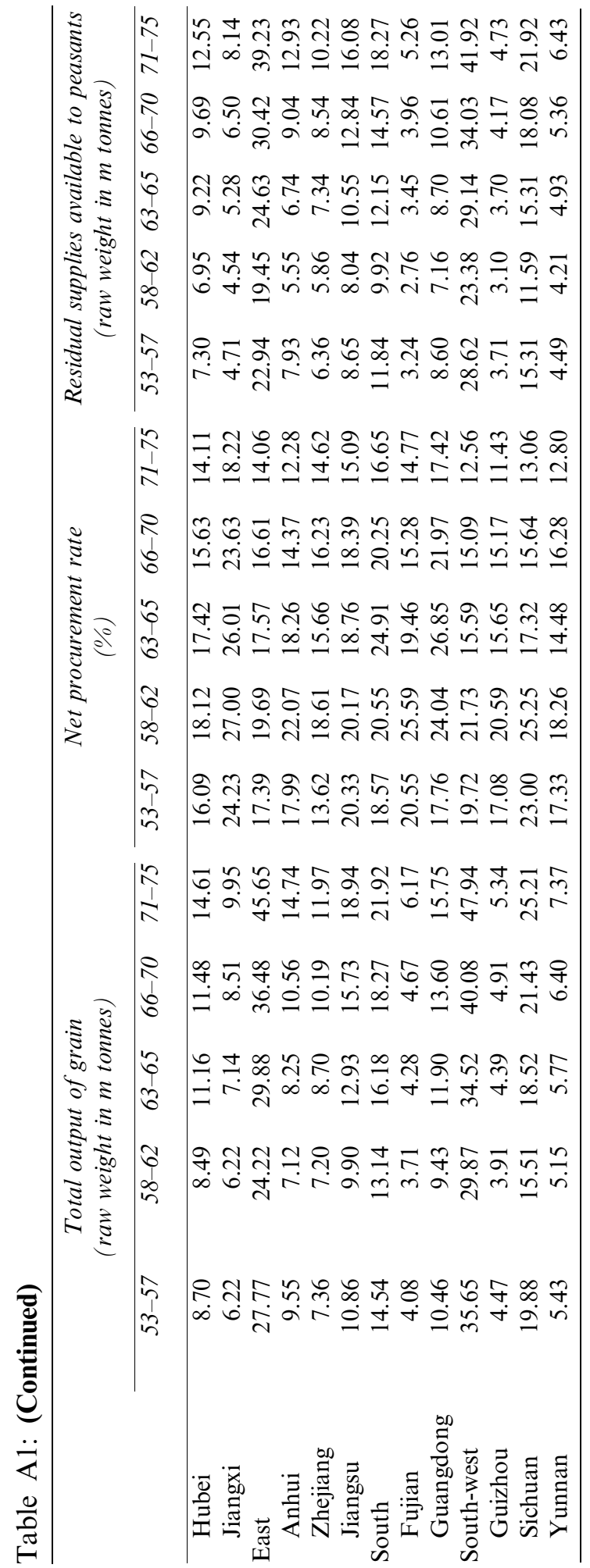




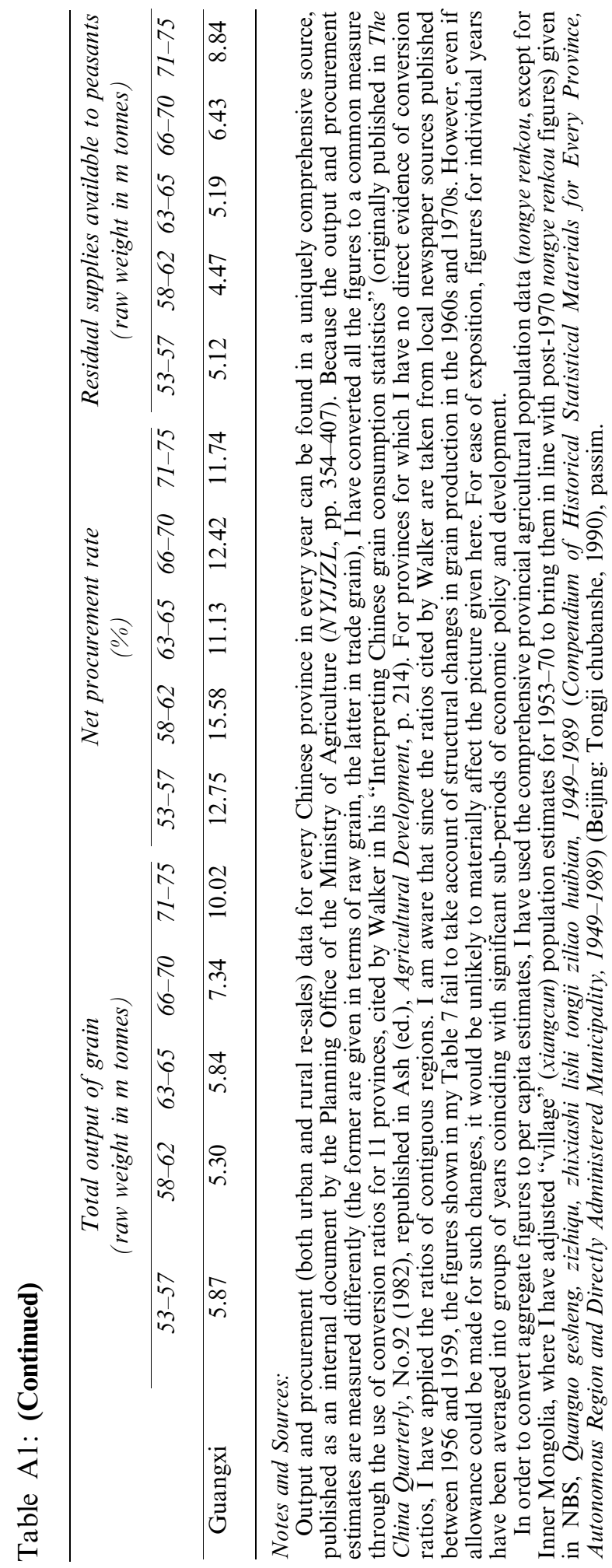




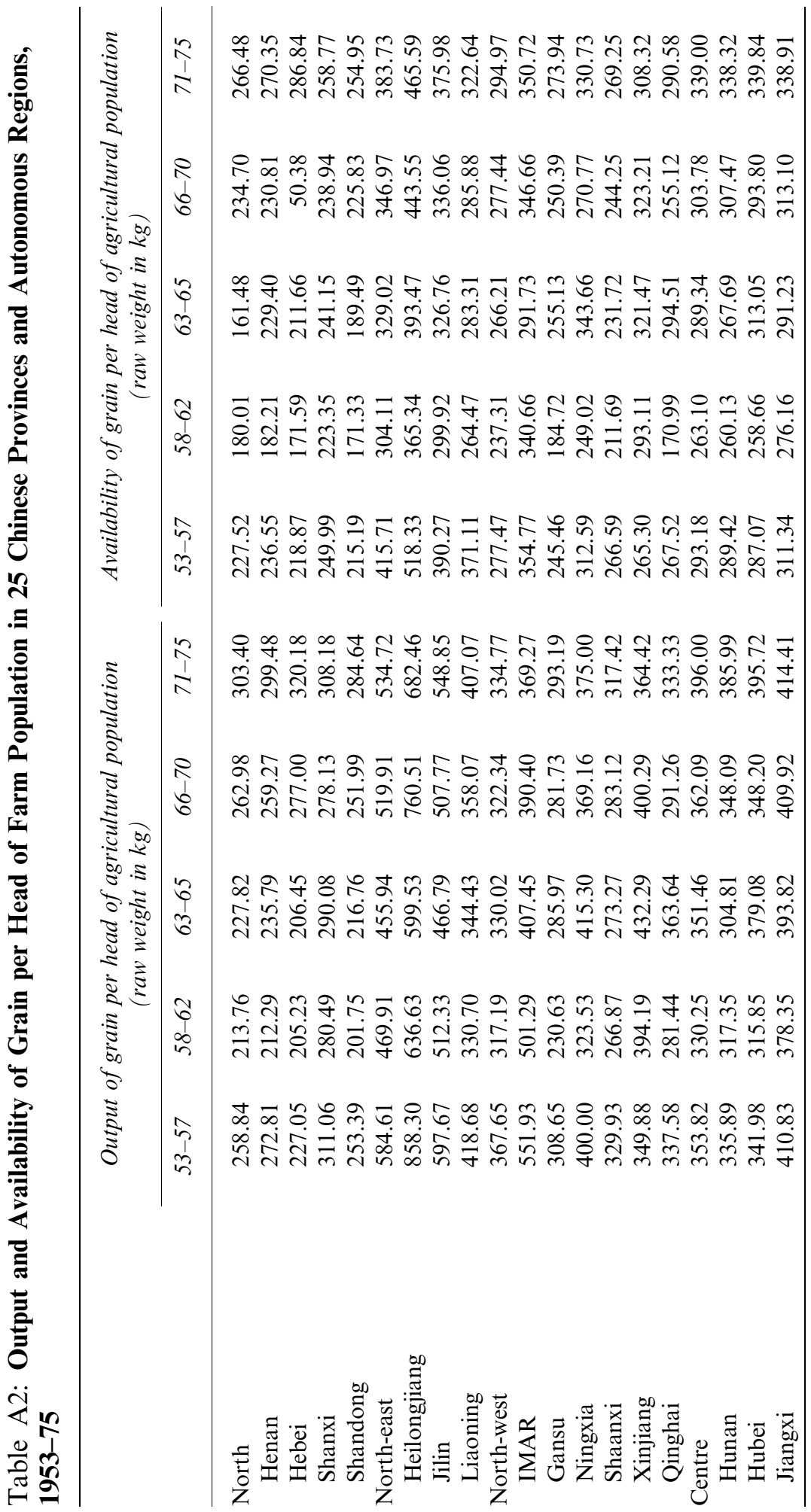




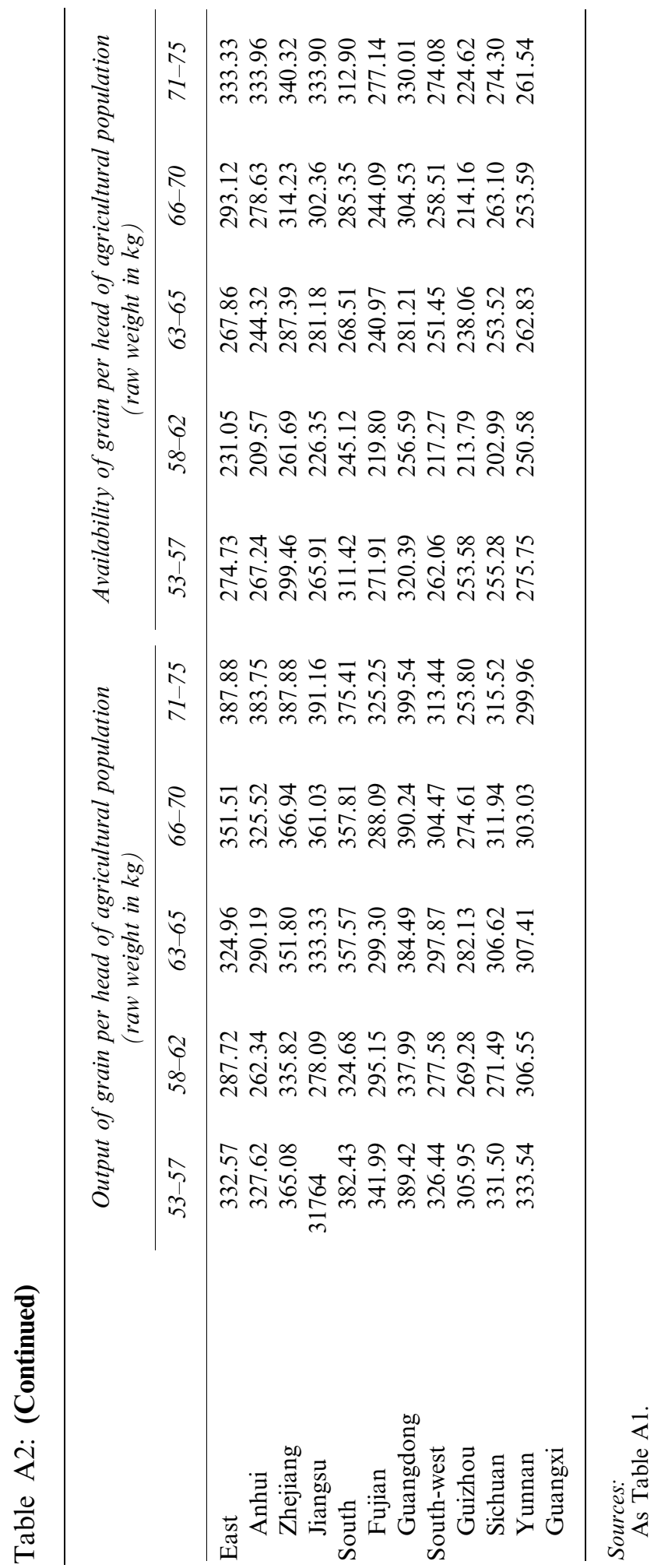

